\title{
Voluntary disclosure, ownership structure, and corporate debt maturity: A study of French listed firms
}

\author{
Manel Allaya \\ Portsmouth Business School, Portsmouth, United Kingdom \\ Imen Derouiche* \\ CREA, University of Luxembourg, Luxembourg \\ Anke Muessig \\ CREA, University of Luxembourg, Luxembourg
}

\begin{abstract}
This study examines the effect of voluntary disclosure on corporate debt maturity and the role of ownership structure in this effect. For a sample of 440 French listed firms from 2007 to 2013, the empirical results indicate that firms with greater voluntary disclosure have more long-term debt, suggesting that companies benefit from extensive disclosure through greater access to long-maturity debt. This finding is consistent with the evidence that voluntary disclosure provides an efficient monitoring mechanism in firms where long-term debt could insulate firms from lender scrutiny for long periods. The results also show that the positive association between voluntary disclosure and long-term debt is relevant only when the control rights of the controlling shareholders are significantly in excess of cash-flow rights. This finding supports recent work showing that better disclosure policies are viewed more positively by the market in environments where the risk of wealth expropriation by dominant shareholders is higher.
\end{abstract}

JEL classification: G32; G34; M41

Keywords: Ownership structure; excess control rights; corporate disclosure; debt maturity.

- Corresponding author: Unité de recherche CREA (FDEF), University of Luxembourg, BRA 3.07,162A, avenue de la Faïencerie, L-1511 Luxembourg; e-mail imen.derouiche@uni.lu; phone +352 4666446155. 


\section{Introduction}

A long line of research documents the importance of agency and information asymmetry problems in the design of debt covenants (e.g., Armstrong et al., 2010; Christensen et al., 2016; Diamond, 1991). ${ }^{1}$ However, how these problems affect the choice between short- and long-term debt remains unclear. Some empirical studies show that firms issue more short-term debt in the presence of efficient governance mechanisms, such as high levels of managerial ownership (Datta et al., 2005), strong boards of directors (Harford et al., 2008), or high contestability of the largest shareholder's control (Ben-Nasr et al., 2015). Other work provides evidence that debt maturities are longer in firms with a better information and monitoring environment, such as one with a higher quality of financial reporting (Bharath et al., 2008; García-Teruel et al., 2010) or stronger external audits (El Ghoul et al., 2016).

The present study extends this line of research by examining the effect of voluntary disclosure on debt maturity structure. This topic is particularly salient but underexplored in firms that predominantly feature concentrated control, such as French firms. It is surprising that this issue has received such scant research attention, given that agency problems arising from concentrated control are dominant in most countries, as argued by La Porta et al. (2002). Indeed, unlike agency problems between shareholders and managers in dispersed ownership firms (Type I agency problems), central agency problems in firms with concentrated control arise from the likelihood of controlling shareholders - who are insiders in this environmentexpropriating minority shareholders and creditors (Type II agency problems).

France provides an excellent laboratory-style setting for studying excess control rights, given the ubiquitous use by French firms of patterns that create a divergence between control rights and cash-flow rights. Indeed, French corporate law allows faithful shareholders (generally the largest shareholders) to be granted a second vote when they hold registered shares beyond a given period. The implementation of double voting rights can be introduced in the

\footnotetext{
1 The agency costs of debt can take different forms. For example, firms may invest in high-risk-high-return projects from which shareholders can benefit handsomely while debtholders would bear most of the cost. Firms can also engage in underinvestment-by undergoing profitable projects-while most of the generated cash flows will be used to pay the debt service. In addition, insiders may pursue short-term capital gains by selecting short-term investment projects at the expense of long-term projects with high net present value (Jensen and Meckling,1976).
} 
articles of incorporation or in the by-laws (Lannoo, 1999). ${ }^{2}$ French firms are also allowed to create non-voting shares (e.g., preferred shares and investment certificates) that give priority in dividends over other types of shares while being deprived of the right of vote. The corporate law generally limits the issuance of nonvoting shares to a relatively small proportion of total equity capital. ${ }^{3}$ Further, it is common for a shareholder to hold an entity through a cascade of listed and unlisted intermediate firms (i.e., pyramid structures), allowing the shareholder to have substantial control over this entity while holding much less equity (Boubaker, 2007). This setting is even more interesting when we consider that France is a civil-law country, which, contrary to common-law countries, provides little protection to minority investors and poor law enforcement, making controlling shareholders more likely to engage in selfdealing behavior (Djankov et al., 2008). Moreover, the literature on debt maturity is largely conducted with data from the United States, which is a common-law country with a capital market-oriented economy that provides a strong protection of creditor rights (La Porta et al., 1997). France-a bank-oriented economy-offers, however, rather poor protection for creditors and exposes lenders to high credit risk (Davydenko and Franks, 2008), making it interesting to understand corporate debt maturity structure in such an environment. ${ }^{4,5}$

Building on the premise that extensive voluntary disclosure is valuable to market participants, especially lenders, we argue that firms can obtain better access to long-term debt when they demonstrate greater voluntary disclosure. ${ }^{6}$ Indeed, increased voluntary disclosure sends a positive signal to the market because it is generally associated with decreased

2 These shares are not allowed to be traded on the stock exchanges or they would be deprived of the second vote.

${ }^{3}$ Examples of these firms are Bouygues, Casino Guichard, Essilor, Legrand, L'Oreal, Pechiney, Sagem, and Société du Louvre.

${ }^{4}$ France receives the score of 0 according the creditor rights index of La Porta et al. (1997) that ranges from a minimum of 0 to a maximum of four.

${ }^{5}$ The authors contend that the French bankruptcy law is "creditor unfriendly" and explain that:

French bankruptcy courts are given control of the bankruptcy process and are not mandated to sell firm assets to the highest bidder. The role of creditors is reduced to an advisory function, and their approval is not required by the court in determining a reorganization plan (p. 566).

${ }^{6}$ In relation to our topic pertaining to the information environment, it is more relevant to examine the maturity of the debt from the offer side. A voluntary disclosure environment would influence the behavior of market participants being more able to form an opinion of the firm risk, which is determinant in a lender's decision to extend credit to the firm (Cole, 1998). Moreover, there are two distinct parties to the implementation of each voluntary disclosure policy and lending policy - the firm and the lending entity, respectively - such that the decision to lend for a long or short period is a response to the firm's observed disclosure strategy. Many papers adopt the offer side perspective when examining debt maturity such as Bharath et al., (2008), García-Teruel et al. (2010), and El Ghoul et al. (2016). 
information asymmetry and better observability of insider actions (Bushman and Smith, 2001; Chung et al., 2015; Lang and Lundholm, 2000). That is, lenders can protect their interests by relying on extensive voluntary disclosure as an effective monitoring device, which is reflected in the ability of firms to issue more long-term debt.

Focusing on 440 French listed firms from 2007 to 2013, univariate analysis shows that the different voluntary disclosure variables are strongly positively correlated with debt maturity, suggesting that firms have more long-maturity debt when they voluntarily divulge a large amount of information. This positive association is substantiated by the results of multivariate analysis that accounts for the joint determination of debt maturity and leverage by estimating a two-stage least squares (2SLS) regression.

We sharpen our analysis by examining how the association between voluntary disclosure and debt maturity varies with the likelihood of controlling shareholders entrenching themselves due to their control rights in excess of cash-flow rights, that is, excess control rights. ${ }^{7}$ This inquiry is motivated by the very evidence from prior studies that controlling shareholders with excess control rights are inclined to misuse firm resources in pursuit of private benefits (e.g., Bennedsen and Nielsen, 2010; Claessens et al., 2002; Johnson et al., 2000). In this context, firms with excess control rights typically exhibit greater corporate transparency to avoid unfavorable financing conditions and alleviate agency costs (Chung et al., 2015; Morris et al., 2011). We argue that the voluntary disclosure of these firms is more valuable to lenders because their greater transparency would facilitate information gathering and increase management monitoring to a greater extent, implying a stronger association between voluntary disclosure and long-term debt.

Evidence from empirical analysis indicates that the positive disclosure effect on debt maturity is significant only for high levels of excess control rights. This means that greater entrenchment of dominant shareholders induces lenders to place more weight on voluntary disclosure in their decision to grant long-maturity debt. This argument lends credence to the contention that better disclosure policies are viewed more positively by the market in

\footnotetext{
7 Research in the French context (e.g., Boubaker, 2007; Faccio and Lang, 2002) documents the ubiquitous use of control-enhancing mechanisms such as double voting shares, nonvoting shares, and/or pyramiding structures.
} 
environments with a higher risk of wealth expropriation by controlling shareholders. Our conclusions are robust to a set of sensitivity tests and endogeneity.

This study contributes to the literature in several ways. First, we significantly advance the debt-contracting literature by studying whether voluntary disclosure can substitute for short-term debt in its monitoring role, resulting in more long-term debt in high-disclosure firms. Second, we extend corporate governance studies showing that firms are granted longer debt maturity when they already offer better monitoring through higher-quality financial reporting (García-Teruel et al., 2010) or stronger external audits (El Ghoul et al., 2016). Our work differs, however, from these studies by addressing voluntary disclosure as a disciplinary device. Third, our research complements the literature on the relationship between ownership structure and voluntary disclosure (e.g., Awartani et al., 2016; Chau and Gray, 2002; Donnelly and Mulcahy, 2008; Jankensgård, 2018; Luo et al., 2006) by exploring the joint effect of excess control rights and voluntary disclosure on debt maturity. ${ }^{8}$ Our work also differs from prior studies since it focuses on ultimate ownership of the largest controlling shareholder rather than on its direct ownership. Fourth, to the best of our knowledge, no prior study investigates the interplay between excess control rights, voluntary disclosure, and debt maturity. Our finding in this respect adds to recent evidence (e.g., Chen et al., 2014; Fang et al., 2017; Hong, 2013; Morris et al., 2011) suggesting that the information environment of firms with concentrated control can be positively perceived by the market.

Our study has relevant implications for both academics and practitioners. It is documented that, in France, listed firms have high fractions of long-term debt in their capital structure, while lenders face an unfavorable institutional environment. ${ }^{9}$ The information environment could thus be a countervailing and viable mechanism through which lenders circumvent any institutional inadequacies and firms benefit from more advantageous financing conditions. This paper provides empirical evidence that corporate disclosure is valuable and economically important for market participants in France, which can be extended to most European countries. Moreover, the study of voluntary disclosure in France is timely, since, in recent years, French firms have gradually adopted the provisions of the

\footnotetext{
8 See, Khlif et al. (2017) for an overview of the main empirical studies on the effect of ownership structure on voluntary disclosure.

${ }^{9} \mathrm{El}$ Ghoul et al. (2016) and Zheng et al. (2012) report that France is among the European countries whose firms have the most long-term debt, with an average of 56.9\% total debt over the period 1991-2006. This fraction is $53.74 \%$ for the period $1998-2013$ according to Ben-Nasr et al. (2015).
} 
European Transparency Directive along with the recommendations of the main French reports on corporate governance introducing, inter alia, the publication of several additional items of information in the annual report.

The remainder of the paper is organized as follows. Section 2 motivates and develops the research hypotheses. Section 3 describes the data and the main variables of the empirical analysis, as well as the results of the univariate analysis. Section 4 presents the empirical design and discusses the results of the multivariate analysis. Section 5 reports the results of robustness checks, additional analysis, and endogeneity tests. Section 6 summarizes the main findings and concludes the paper.

\section{Hypothesis development}

\subsection{Voluntary disclosure and debt maturity}

Since the promulgation of the Transparency Directive (Directive 2004/109/EC), competent authorities in France have joined together in an effort to implement appropriate guidelines that facilitate the compliance of French public firms with this directive. ${ }^{10}$ In particular, many recommendations for improving voluntary disclosure in annuals reports have been developed by specialized organizations such as the Association française des entreprises privées-Mouvement des entreprises de France (Afep-Medef) and Association française de la gestion financière (AFG). ${ }^{11}$ The French regulatory authority Autorité des Marchés Financiers (AMF) enforces many of these recommendations through "implementing" provisions. ${ }^{12}$

The accounting literature is replete with arguments expounding the merits of voluntary disclosure in reducing adverse selection and moral hazard problems. Indeed,

\footnotetext{
${ }^{10}$ Apart of information in the annual reports, the Transparency Directive requires the publication of halfyearly financial reports comprising condensed financial statements, as well as a narrative interim management statement describing the firm's financial position and performance. The transposition of the revised Transparency Directive into French law was completed in December 2015.

${ }^{11}$ For example, a recent version (issued in 2016) of the AFG report suggests that the annual report includes detailed information on non-executive chairperson compensation, as well as the auditor's special report on related-party transactions. It also encourages the use of a language other than French, notably the English language.

12 For example, in 2008, 88.5\% of SBF 120 companies complied with Afep-Medef's recommendation to report detailed information on individual executive compensation in conformity with an AMF implementation provision (see Y. Le Galès, "Salaires: Les patrons plus transparents," Le Figaro, November 18, 2009).
} 
increased voluntary disclosure is generally associated with decreased information asymmetry and the greater ability of outsiders to monitor management (Bushman and Smith, 2001; Chung et al., 2015; Haggard et al., 2008; Hermalin and Weisbach, 2012). This involves disclosing bad news that would warn the market of negative earnings surprises, such that firms can mitigate litigation costs and preserve reputation (Kasznik and Lev, 1995). Nondisclosure is negatively interpreted by the market, since it offers great opportunities for misreporting (Dhaliwal et al., 2011a). In sum, comprehensive voluntary disclosure sends a positive signal to the market because it reflects the efforts of insiders toward increasing the observability of their actions and mitigating agency problems.

Voluntary disclosure can be especially valuable to lenders, who can use private information to appropriately assess a firm's creditworthiness (Healy and Palepu, 2001), as well as verify and monitor corporate compliance with debt covenants (El Ghoul et al., 2016). A number of studies support the debt-related benefits of voluntary disclosure by showing, for example, that higher disclosure levels are associated with the reduced cost of capital (Dhaliwal et al., 2011a; Easley and O'Hara, 2004) and lower costs of debt (Mazumdar and Sengupta, 2005). ${ }^{13}$ With respect to debt maturity, an extensive literature documents that short-term debt implies lower agency costs to the extent that, under information asymmetry, the frequent renewal of this debt allows for the recurrent monitoring of managerial actions (e.g., Barclay and Clifford, 1995; Barnea et al., 1980; Myers, 1977). ${ }^{14}$ However, greater corporate transparency can increase lenders' confidence in a firm and thus substitute for short-term debt in its monitoring role, leading to more long-term debt (Berger et al., 2005; Godlewski, 2015). ${ }^{15}$

Consistent with this view, La Porta et al. (2003) and Charumilind et al. (2006) show that firms with close ties with banks are more likely to issue long-term debt, because bankers

\footnotetext{
${ }^{13}$ Despite the potential disadvantages of disclosure such as proprietary information leakage, the disclosure gains resulting from obtaining financing at favorable terms generally seems to outweigh the disclosure costs (Verrecchia, 1983, 2001).

${ }^{14}$ Even though this is the dominant view in the literature, Roberts and Sufi (2009) report that, in practice, more than $90 \%$ of long-term loans are renegotiated before they mature - and this following the availability of new information on the borrower or following macroeconomic fluctuations. This finding also suggests that corporate debt maturity structure is influenced by factors outside the firm's control, which reinforces the offer side adopted by the present research.

${ }^{15}$ Lenders are also encouraged to grant firms long-term debt because this allows them to control the firms' credit risk and increases their bargaining power, since they can seize and liquidate collateral in the event of default (Shleifer and Vishny, 2011).
} 
can more easily obtain private information about "related firms" and use this information to monitor managerial investment decisions. Bharath et al. (2008) and García-Teruel et al. (2010) report that higher reporting quality can substitute for the monitoring role of short-maturity debt, allowing firms to have longer-maturity debt. Similarly, El Ghoul et al. (2016) show that strong external monitoring by a Big Four auditor implies more long-term debt.

Given that an expanded disclosure policy is consistent with an improvement in the firm's information and monitoring environment, the above arguments suggest that firms would issue more long-term debt when they have greater voluntary disclosure. Therefore, we formulate our first hypothesis as follows.

\section{H1: Firms with higher levels of voluntary disclosure have more long-term debt.}

\subsection{Excess control rights, voluntary disclosure, and debt maturity}

Assuming that firms with higher voluntary disclosure are more entitled to longmaturity debt, we investigate whether this hinges on the entrenchment of controlling shareholders with control rights in excess of cash-flow rights, that is, excess control rights. Consistent with the corporate governance literature, more excess control rights are associated with a higher likelihood of controlling shareholders misusing firm resources in pursuit of private benefits (e.g., Bennedsen and Nielsen, 2010; Claessens et al., 2002; Johnson et al., 2000). 16

Since excess control rights are a typical channel of private benefit extraction by controlling shareholders, corporate disclosure could represent a form of outsider protection that reduces the scope of these benefits (Östberg, 2006). The dissemination of high-quality information, in particular, increases outsiders' ability to monitor managerial actions and avert any opportunistic behavior (Berglöf and Pajuste, 2005). In this respect, Morris et al. (2011) report that, following the Asian financial crisis, the demand for the transparency of firms involved in pyramid structures - where the divergence between control rights and cash-flow rights is ubiquitous and tunneling through related-party transactions is more likely-increased as a remedy for the potentially high private benefits of controlling shareholders in these structures.

\footnotetext{
16 These benefits can take different forms, such as engaging in unprofitable investments that generate private gains for the controlling shareholder, transferring cash and profits to other firms under that shareholder's control, paying low dividends, or issuing loan guarantees using the firm's assets.
} 
In support of this view, Hong (2013) finds that the adoption of mandatory International Financial Reporting Standards (IFRS) in dual-class firms provides an effective mechanism for constraining private benefits. Chung et al. (2015) show that the role of voluntary disclosure in mitigating agency costs associated with excessive executive compensation is more prominent among group-affiliated firms than among independent firms. In a related vein, Fang et al. (2017) show that Chinese group-affiliated firms are more likely to select the top 10 audit firms to improve reporting quality. The authors also report that group firms benefit from such strong external monitoring because they enjoy higher value and cheaper equity financing. This result is in line with the claim of Boubaker and Labégorre (2008) that the private information of firms with greater excess control rights is valued more highly by the market, leading to a larger analyst following.

Lenders are particularly aware of the risk of being expropriated by controlling shareholders, which explains the tighter debt terms that are often imposed on firms with excess control rights, such as higher costs of debt (Boubakri and Ghouma, 2010) or borrowing costs (Lin et al., 2011). This can create a context wherein corporate disclosure serves as a valid signal of value to the market. In this respect, Chen et al. (2014) show that the positive effect of corporate transparency on debt maturity is more pronounced among family firms compared to other firms, because the greater transparency of family firms would be more valuable to outsiders as a mechanism for reducing the scope for expropriation by the controlling families.

Taking all the above arguments into account, we predict that voluntary disclosure will be more valuable to lenders in firms with higher excess control rights because the greater transparency of such firms would facilitate information gathering and increase management monitoring to a greater extent. This matters because of higher demand for private information about firms in which the likelihood of expropriation is higher (Chen et al., 2014; Fang et al., 2017) such as firms with excess control. Therefore, assuming that the (positive) effect of voluntary disclosure on debt maturity reflects the disciplinary role of corporate disclosure, we expect this effect to be more prevalent among firms with higher levels of excess control rights. We thus suggest the following hypothesis.

H2: The (positive) effect of voluntary disclosure on debt maturity is more pronounced among firms with higher excess control rights. 


\section{Data}

This section describes the sample selection procedure and data sources and discusses the construction of the voluntary disclosure indexes, as well as the choice of control variables. It also presents descriptive statistics and the results of the univariate analysis.

\subsection{Sample selection and data sources}

The initial sample includes all publicly listed French firms available in the Worldscope database for the 2007-2013 period. We end the analysis in 2013 because of the promulgation in 2014 of the Florange Act stipulating, in particular, that double voting is the default rule for any nominative listed stock that is held for at least two years (unless the one share, one vote principle is explicitly included in the company's bylaws). Such a provision could increase the separation of control and cash-flow rights in a substantial way, thus altering our analysis of the effect of excess control rights on corporate debt structure. Financial firms (Standard Industrial Classification, or SIC, codes 6000-6999) and regulated utilities (SIC codes 4900-4999) are excluded because of their specific legal and regulatory requirements, consistent with prior literature. Observations missing financial or governance data are also discarded from the sample. The screening process results in a total of 440 firms for 2,485 firm-year observations. Data on voluntary disclosure are manually gathered from the companies' annual reports. Financial data are retrieved from the Worldscope database.

\subsection{Main variables}

\subsubsection{The voluntary disclosure indexes}

To measure voluntary disclosure, we identify a subset of nonmandatory information

items that are disclosed in firm annual reports and we construct different voluntary disclosure indexes. Voluntary disclosure in annuals reports is of great interest for several reasons. First, disclosing additional information beyond mandatory requirements reflects the flow of private communications from the firm, which is the primary concern for lenders (Dhaliwal et al., 2011b). The level of disclosure in annual reports also tends to be positively associated with the extent of other types of public disclosure, such as those conveyed via investor relations services (Lang and Lundholm, 1993). Second, annual reports divulge a variety of financial and nonfinancial information, which allows different aspects of voluntary 
disclosure policy to be considered, such as historical and forward-looking information, as well as a variety of corporate governance information. ${ }^{17}$ Third, most other reporting quality indicators in the literature, such as earnings management and analyst forecasts, are essentially accounting-based measures and are often relatively complex to set up and to interpret for market participants (Li, 2008).

Interestingly, many studies use a self-constructed index to gauge general voluntary disclosure (e.g., Chau and Gray, 2010; Francis et al., 2008; Morris et al., 2011) or specific disclosures, such as those on the environment (Meng et al., 2013) or executive compensation (Chung et al., 2015; Melis et al., 2015). We do not use management earnings guidance as in most of the recent U.S. research, since that such a report (or its equivalent) does not exist in France. ${ }^{18}$ Moreover, disclosure indexes have the advantage of taking into account variation in the information flow, compared to the dummy management guidance variable. In addition, our self-constructed index includes, inter alia, items reflecting management forecasts.

To construct our overall disclosure index OVERALL_VDI, we establish a list of 73 items that are compiled from prior voluntary disclosure literature (e.g., Botosan, 1997; Eng and Mak, 2003; Meek et al., 1995). All items are checked against regulatory disclosure requirements to verify that they remain adapted to the French context. We hand-collect these items directly from the firms' annual reports (or reference documents). An item is coded one if it is disclosed in the annual report, 0 if it is not, and N/A if it is not applicable to the firm. The variable OVERALL_VDI is measured as the sum of items coded one, divided by the maximum possible items for a given firm, excluding inapplicable items.

The listed items fall into one of two significant categories, namely, governance information (47 items) and financial information (18 items). Correspondingly, two refinements of the voluntary disclosure measure are used. We construct a governance disclosure index GOV_VDI and a financial disclosure index FIN_VDI. The governance disclosure index includes information on major shareholders and managers, as well as information on the board of directors, directors, committees, and external auditors. The

\footnotetext{
17 For example, Amir and Lev (1996) show that the voluntary disclosure of nonfinancial information on intangible assets is markedly more value relevant to investors than financial information is.

18 The use of a voluntary disclosure index could thus increase the comparability of our results with those of prior research from outside the United States.
} 
financial disclosure index comprises historical, current, and forward-looking information. We do not consider a specific index for general information items, given their limited number (eight items). Relevant to our interest in information and agency problems between insiders and outsiders, we also construct an insider disclosure index INS_VDI that captures the extent of information about insiders (managers and controlling shareholders), including, inter alia, their ownership, votes, compensation, and personal profiles (15 items). See Appendix 1 for the list and categories of the items used to construct the four voluntary disclosure indexes.

Following prior empirical studies using self-constructed disclosure indexes, we measure Cronbach's (1951) alpha to assess the internal consistency of our four voluntary disclosure measures. Cronbach's alpha ranges from zero to one and measures the degree to which correlations among the different disclosure indexes are weakened due to random error. We obtain an alpha of 0.77 , which is an acceptable value to determine that our disclosure indexes record the same underlying construct and are thereby valid. ${ }^{19}$

\subsubsection{Debt maturity}

In our main regressions, the dependent variable DEBT_MATURITY is measured as the ratio of long-term debt to total debt, following previous research (e.g., El Ghoul et al., 2016; Zheng et al., 2012). Alternative measures of debt maturity are used for robustness checks.

\subsubsection{Excess control rights of controlling shareholders}

Excess control rights gauge the wedge between the control rights and cash-flow rights of the ultimate controlling shareholder. We identify the ultimate controlling shareholder as the individual or entity owning the largest control rights stake (the proportion of direct and indirect voting rights) that equals or exceeds $10 \% .{ }^{20}$ We thus conventionally assume that a shareholder who controls, directly or indirectly, at least $10 \%$ of the votes can exert effective control over the firm, which is consistent with very thorough studies related to disproportional ownership (e.g., Faccio and Lang, 2002; La Porta et al., 1999). If the firm does

\footnotetext{
${ }^{19}$ There is no standard test of significance for this statistic. By comparison, Botosan (1997) finds an alpha of 0.64 and Gul and Leung (2004) find an alpha of 0.7.

${ }^{20}$ The use of a $20 \%$ control level leads to qualitatively unchanged results, as shown by the results of robustness checks.
} 
not have at least one shareholder with $10 \%$ or more of the control rights, the firm is considered widely held.

To measure the excess control rights of the controlling shareholder, we first trace, year by year, the control chain(s) in the pyramidal structure back to the ultimate owner, considering the $10 \%$ control level. We collect data on the ownership and votes of the largest direct owner from the company's annual report and we complete these with information on the ownership and votes of the largest owner of this owner and so on. We thus build the control chains of the pyramid structure until we reach the ultimate owner, identified as the largest shareholder not controlled by another shareholder at the $10 \%$ control level. The ultimate owner can be an individual (a family), a widely held firm, a widely held financial institution, employees, or miscellaneous (cooperative, charity, etc).

We next compute the control rights and cash-flow rights of the ultimate owner following the literature on disproportional ownership (e.g., Claessens et al., 2000; Faccio and Lang, 2002). Control rights are computed as the sum of the weakest links of voting rights along each control chain. Cash-flow rights are obtained as the sum of the products of ownership stakes along the different control chains. The excess control rights of the controlling shareholder, EXCESS, are the difference between control rights and cash-flow rights, divided by control rights.

\subsubsection{Control variables}

We control for a number of firm characteristics likely to affect the corporate debt maturity structure, consistent with prior studies (e.g., Barclay and Smith, 1995; Datta et al., 2005; Myers, 1977; Zheng et al., 2012), as follows. ${ }^{21}$

(i) Firm leverage (LEVERAGE) is the ratio of total debt to total assets. This variable is expected to be positively linked to debt maturity. Indeed, firms can face a higher risk of liquidity shortage when they have more leverage, making them more likely to lengthen the maturity of their debt.

\footnotetext{
${ }^{21}$ In untabulated tests, we considered many other control variables, including the cash-flow rights of the ultimate owner, firm age, the return on equity, the return on assets, capital expenditure, research and development, accounting quality, and audit quality. We find that the results remain qualitatively unchanged.
} 
(ii) Asset maturity (ASSET_MATURITY) is defined as the weighted average of the maturities of current and long-term assets, where the maturity of current assets is current assets divided by the cost of goods sold and the maturity of long-term assets is the ratio of gross property, plant, and equipment to depreciation and amortization. We expect this variable to have a positive impact on the use of long-term debt. Indeed, long-term debt typically matures at the same time as the cash flows generated from the assets that are covered by this type of debt, whereas the maturity of short-term debt does not commonly match the cash flow timing and should hence be frequently refinanced. This argument implies that the maturity matching principle reduces the agency cost of debt and encourages creditors to lend long term.

(iii) The market-to-book ratio $(M T B)$ is computed as the market value of equity divided by the book value of equity. It is used to proxy for the firm's growth opportunities, following standard convention in the literature. This variable is expected to be negatively associated with debt maturity. Firms with more growth opportunities could, indeed, shorten the maturity of their debt to help mitigate information asymmetry and the resulting conflicts with debtholders over the completion of these projects.

(iv) The performance variability (STD_ROA) is measured as the standard deviation of a firm's return on assets over the previous five years. This variable gauging firm risk is expected to be negatively linked to debt maturity. Firms with greater performance variability - that is, greater unpredictability - will face higher credit risk, causing them to be more likely limited to short-term debt.

(v) Abnormal earnings $(A B N E)$ are measured as the ratio of change in earnings before interest, taxes, depreciation, and amortization (EBITDA) over the period $[t, t+1]$ to the market value of equity in year $t$. This variable proxies for firm quality and is expected to have a negative effect on debt maturity, since, consistent with the signaling hypothesis, higherquality firms tend to issue more short-term debt to subject themselves to more frequent monitoring by lenders.

(vi) Firm size (SIZE) is measured as the natural logarithm of total assets (in thousands of euros). This variable is expected to be positively related to debt maturity. Because larger firms tend to have higher credit quality, given their higher expected cash flow, it easier for them to obtain more long-term debt. 


\subsection{Summary statistics and univariate analysis}

Table 1 reports summary statistics for the variables in the main analysis. All the financial variables are winsorized at the first and 99th percentiles to reduce the effects of outliers. Panel A provides descriptive statistics on variables used in the main analysis. The average (median) value of the general voluntary disclosure index OVERALL_VDI is $40.72 \%$ $(43.54 \%)$, indicating the relatively high likelihood of French firms disclosing private information. The sampled firms have average (median) GOV_VDI, INS_VDI, and FIN_VDI values of, respectively, $49.71 \%$ (55.55\%), 59.11\% (56.25\%), and 32.92\% (36.63\%), suggesting that the content of information voluntarily disclosed primarily pertains to corporate governance information, and to a lesser extent, to financial information. Moreover, we find that controlling shareholders' excess control rights have a mean (average) of $22.29 \%$ (20.39\%), showing that this topic is of more than theoretical interest. These values are, in addition, consistent with prior studies focusing on France (Boubaker and Labégorre, 2008; Boubaker et al., 2015).

The results also indicate that, on average, $55.73 \%$ of total debt is long term, with a median value of $61.22 \%$. This pattern of debt maturity is similar to that reported in other studies in the French context, such as those of Zheng et al. (2012) and Ben-Nasr et al. (2015), who document average ratios of long-term debt to total debt of $56.9 \%$ and $53.74 \%$, respectively. The leverage ratio is $21.05 \%(17.91 \%)$ for the average (median) firm. The mean (median) value of asset maturity for our sample is 5.0437 (2.5546). We also document an average (median) market-to-book ratio of 1.8205 (0.6333). The performance variability and abnormal earnings have an average (median) of 7.03\% (3.22\%) and $6.92 \%(0.74 \%)$ The mean (median) natural logarithm of firm size is 14.8344 (14.1688). Overall, these results are consistent with the above-mentioned studies focusing on the French context.

Panel B provides mean values of variables of interest by year. The results report that, overall, the extent of voluntary disclosure does not change substantially over time, despite a slight increase in the years after the 2007-2008 financial crisis. We also notice a decreasing trend in excess control rights, which may indicate a lesser presence of complex ownership structures over the study period. Moreover, we find that debt maturity slightly increases 
immediately after the financial crisis but it recovers to its pre-crisis level two years subsequently.

\section{[Insert Table 1 about here]}

Table 2 reports the results of $t$-test differences of the means of debt maturity by year, as well as over the entire period. The mean values of debt maturity for 2007-2013 are 50.49\% and $62.60 \%$ when OVERALL_VDI is, respectively, below and above the median. The difference is significant at the $1 \%$ confidence level. This result holds for the year-by-year comparison analysis. This indicates that firms have marginally more long-term debt in their capital structure given high levels of voluntary disclosure compared to low levels. Similar results are found when using alternative voluntary disclosure variables. Thus, over the whole sample period, the average long-term debt figures for firms with GOV_VDI, INS_VDI, and FIN_VDI above the median are, respectively, 60.77\%, 65.37\%, and 58.08\%. These values decrease significantly to $49.16 \%, 52.22 \%$, and $58.08 \%$ when, respectively, GOV_VDI, INS_VDI, and FIN_VDI are below the median. This difference in debt maturity between firms with low and high voluntary disclosure is also significant across the years of our analysis (except for the variable FIN_VDI in 2007 and 2008). Our findings provide preliminary evidence on the association between voluntary disclosure and long-maturity debt.

\section{[Insert Table 2 about here]}

\section{Multivariate analysis}

This section describes our baseline model specification. It also reports the results of the effect of voluntary disclosure on debt maturity and the role of excess control rights in this relation.

\subsection{Baseline model specification}

To test our research hypotheses, we estimate the following model specification:

$$
\begin{aligned}
& \text { DEBT_MATURITY }=\beta_{0}+\beta_{1} * V D I+\beta_{2} * \text { LEVERAGE }+\beta_{3} * \text { ASSET_MATURITY }+\beta_{4} * \\
& M T B+\beta_{5} * S T D_{-} R O A+\beta_{6} * A B N E+\beta_{7} * S I Z E+\beta_{8}(\text { Industry Dummies })+\beta_{9} * \\
& \text { (Year Dummies })+\varepsilon_{i}
\end{aligned}
$$

where Industry Dummies and Year Dummies are sets of year and industry fixed effects, respectively, included in the model to capture variations over time and across industries in 
debt maturity and voluntary disclosure. Industries are identified using the SIC classification of Campbell (1996). All the other variables are described in Appendix 2. The financial variables are winsorized at the first and 99th percentiles to reduce the effects of outliers.

We follow prior literature on debt maturity (e.g., Billett, 2007; Kirch and Terra, 2012; El Ghoul et al., 2016) and we account for the joint determination of debt maturity and leverage by estimating a 2SLS regression. The fitted values of leverage are obtained from the following first-stage estimation of the 2SLS regression:

LEVERAGE $=\beta_{0}+\beta_{1} * P P E+\beta_{2} * R O A+\beta_{3} * M T B+\beta_{4} * S T D_{-} R O A+\beta_{5} * S I Z E+\beta_{6} *$

REGULATED $+\beta_{7}$ (Industry Dummies $)+\beta_{8} *($ Year Dummies $)+\varepsilon_{i}$

where PPE is the ratio of net plant, property and equipment to total assets and REGULATED is a dummy variable that equals 1 if the firm belongs to a regulated industry (e.g., railroads, SIC code 4011; trucking, SIC codes 4210 and 4213; airlines, SIC code 4512; and telecommunications, SIC codes 4812 and 4813), and 0 otherwise. The other variables are described in Appendix 2. The financial variables are winsorized at the first and 99th percentiles.

\subsection{Effect of voluntary disclosure on debt maturity}

Table 3 reports the results from estimating the effect of voluntary disclosure on debt maturity structure using 2SLS regressions. Specification (1) includes the general voluntary disclosure index OVERALL_VDI along with the main determinants of debt maturity. The results show that the coefficient of OVERALL_VDI is positive and statistically significant at the $1 \%$ level. This result is also economically important in that, ceteris paribus, the proportion of long-term debt in firms' capital structures rises by $31.89 \%$ with a one-point increase in the general voluntary disclosure index. The results from specifications (2) to (4) also show that the coefficients of, respectively, GOV_VDI, INS_VDI, and FIN_VDI are strongly positive and economically significant, with proportions of long-term debt that rise by $23.07 \%, 12.77 \%$, and $10.41 \%$ with a one-point increase in the voluntary disclosure index associated with, respectively, corporate governance, insider, and financial information. This finding means that the increase of long-term debt with voluntary disclosure is greater when such a disclosure concerns, first, information on corporate governance, then information on insiders, and, lastly, financial information. This result indicates that the different types of voluntary 
disclosure do not likely to affect lenders' decisions to lend long term to the same degree. In particular, it seems that lenders are more interested in the quality of corporate governance, which reinforces the notion that voluntary disclosure is considered per se an effective monitoring and corporate governance mechanism.

Overall, these findings support the prediction of H1, that firms access more long-term debt when they provide greater voluntary disclosure, which is consistent with recent empirical evidence that longer maturity debt is essentially the outcome of a positive perception of a firm's information and monitoring environment (e.g., El Ghoul et al., 2016; Godlewski, 2015).

All the control variables, except for the market-to-book ratio, are statistically significant and have the expected sign, consistent with prior studies in this area (e.g., Barclay and Clifford, 1995; Billett et al., 2007; Zheng et al., 2012). Thus, we find that higher leverage leads to longer debt maturity as a way to avoid liquidity risk. Asset maturity is also found to be positively associated with debt maturity, which is consistent with the view that firms are more likely to match the maturity structure of their assets and their liabilities to avoid debt repayment problems. The results indicate that, in contrast, debt maturity decreases with the volatility of the return on assets, corroborating that lenders of long-term debt tend to preclude risky firms. As expected, we find a negative impact of abnormal earnings on debt maturity, meaning that high-quality firms signal that they are better monitored through issuing shortterm debt. We also support the view that larger firms have longer debt maturity because they enjoy lower credit risk. ${ }^{22}$

\section{[Insert Table 3 about here]}

\subsection{Effect of ownership structure on the relation between voluntary disclosure and debt maturity}

In this section, we analyze whether and how the (positive) effect of voluntary disclosure on debt maturity varies with the presence of controlling shareholders with control rights in excess of cash-flow rights.

22 In an untabulated test, we further control for the financial crisis period (2007-2008) and find that the results remain unchanged. 
Table 4 reports the results from the sample-splitting technique consisting in classifying firms into Low EXCESS or High EXCESS groups, depending on whether the variable EXCESS is below or above the median value of the distribution. ${ }^{23}$ The results show that the coefficients of the four voluntary disclosure indexes OVERALL_VDI, GOV_VDI, INS_VDI, and FIN_VDI are positive and statistically significant at the $1 \%$ level in the High EXCESS groups (specifications (2), (4), (6), and (8)). In contrast, the voluntary disclosure coefficients are statistically indistinguishable from zero across the Low EXCESS groups (specifications (1), (3), (5), and (7)). The magnitude of the disclosure coefficient is also higher in the High EXCESS groups. Our results are economically relevant, given that firms with extensive voluntary disclosure as proxied by OVERALL_VDI, GOV_VDI, INS_VDI, and FIN_VDI experience, respectively, 49.59\%,34.07, 20.61\%, and 18\% higher long-term debt when they have high excess control rights compared to when they have low excess control rights. In addition, these significant coefficients exceed those observed in Table 4 for the whole sample. We note that, overall, the results for the control variables are very similar to those reported before.

In summary, our results are consistent with the prediction of $\mathrm{H} 2$ that high levels of controlling shareholders' excess control rights strengthen the positive effect of voluntary disclosure on long-term debt. This finding lends credence to the contention that voluntary disclosure is more valuable to lenders in firms with higher excess control rights, arguably because greater transparency for such firms would facilitate information gathering and increase monitoring by the market to a greater extent. We thus complement prior recent evidence on the importance of corporate transparency in reducing agency problems in firms where the risk of wealth expropriation by controlling shareholders is already high (Chen et al., 2014; Chung et al., 2015). Our results also suggest that controlling shareholders could gain more benefits from corporate transparency - by obtaining more long-term debt - than from extracting private benefits of control.

\section{[Insert Table 4 about here]}

\footnotetext{
${ }^{23}$ We test our second hypothesis using the sample-splitting technique rather than the interaction variable technique to avoid multicollinearity issues stemming from the high correlations between the test variables and their interaction terms, especially when the interactions involve a dummy variable (e.g., El Ghoul et al. 2016; Guedhami et al. 2009).
} 


\section{Robustness checks, additional analysis, and endogeneity}

\subsection{Alternative variable measures}

In Table 5, we test the robustness of the results regarding H1 (specifications (1) and (2)) and H2 (specifications (3)-(8)).

First, we use the dummy measure of debt maturity, DEBT_MATURITY DUMMY, which equals 1 when the ratio of long-term debt to total debt exceeds $50 \%$, and 0 otherwise (specification (1)). We rerun our main regression using the general voluntary disclosure index and find that the variable OVERALL_VDI is positive and significant at the $1 \%$ level, thus corroborating the positive significant effect of voluntary disclosure on debt maturity.

Second, consistent with the work of Ben-Nasr et al. (2015), we measure debt maturity, DEBT_MATURITY1, as the difference between total liabilities and current liabilities, divided by total liabilities (specification (2)). The results indicate, again, that debt maturity is positively related to voluntary disclosure.

Third, we use alternative measures of excess control rights, namely, the ratio of control rights to cash-flow rights (specifications (3) and (4)), the difference between control rights and cash-flow rights (specifications (5) and (6)), and the variable EXCESS taken at the 20\% control level (specifications (7) and (8)). The results show that the coefficient of the voluntary disclosure index continues to be positive and statistically significant at the $1 \%$ level for the High EXCESS groups (specifications (4), (6), and (8)) and is indistinguishable from zero for the Low EXCESS groups (specifications (3) and (5)) or weakly statistically significant (specification (7)). Taken together, these findings corroborate our contention that high levels of excess control rights reinforce lenders' reliance on voluntary disclosure, allowing highdisclosure firms to access more long-term debt.

\section{[Insert Table 5 about here]}

\subsection{Alternative sample compositions}

In this section, we check whether our first hypothesis is robust to alternative sample compositions. The results are reported in Table 6. First, we ensure that our results are not driven by the presence of institutional controlling shareholders, who typically have simultaneous holdings of significant equity positions and debt claims in the firm, consistent with several studies (e.g., Jiang et al., 2010). Indeed, these shareholders could want to signal 
to the market their effective corporate disclosure by accompanying the increase in voluntary disclosure with an increase in long-term debt. Thus, we re-estimate our baseline specification by excluding firms in which the controlling shareholder is a financial institution (i.e., bank, insurance company, private equity, mutual fund, pension fund, real estate) or the state (specification (1)). The coefficient of the voluntary disclosure variable continues to be positive and statistically significant at the $1 \%$ level, meaning that the positive disclosure effect on debt maturity is not affected by the influence of institutional shareholders over firm policies.

Second, we conduct our analysis after excluding firms with no shareholders holding at least $10 \%$ of control rights (i.e., widely held firms) to check that our results are not due to the absence of agency problems between controlling shareholders and minority investors (specification (2)). Our main findings remain unaffected.

Third, the presence of controlling shareholders with important cash-flow rights could give them greater incentives to align their interests with those of shareholders, notably by extending voluntary disclosure. To ensure that our results are not driven by the disclosure incentives of dominant shareholders with substantial cash-flow rights, we rerun our main regression on the sample of firms in which controlling shareholders hold relatively nonsubstantial cash-flow rights, that is, less than $25 \%$ (specification (3)). The results confirm that the voluntary disclosure effect on the maturity of debt is strongly positive, indicating that voluntary disclosure is a valuable monitoring device for lenders who are less likely to rely on other internal corporate governance mechanisms.

Fourth, the presence of multiple large shareholders-beyond the largest-could reinforce management monitoring, implying lower information and agency problems, making transparent firms more likely to negotiate favorable debt terms. To mitigate the concern that our results are driven by the presence of multiple large shareholders, we estimate our baseline model by excluding firms with more than one controlling shareholder (specification (4)). The results reveal again that voluntary disclosure positively affects debt maturity.

Fifth, studies such as those of Claessens et al. (2002) and Johnson et al. (2000) recognize that, unlike stand-alone firms, group-affiliated firms are complex and opaque structures where management monitoring is costly and difficult. To mitigate concerns that our results are due to better monitoring abilities in stand-alone firms, we limit our analysis to the sample 
of group-affiliated firms and find that the results yield the same evidence of positive and significant disclosure on debt maturity (specification 5).

\section{[Insert Table 6 about here]}

\subsection{Alternative statistical approaches}

Table 7 presents the results of robustness checks to alternative statistical approaches. First, we rerun our baseline regression using a Tobit model (specification (1)). The resulting coefficient of the voluntary disclosure index OVERALL_VDI is again positive and highly significant at the 1\% level, consistent with our main finding that the fraction of long-term debt in capital structure increases with the extent of a firm's voluntary disclosure.

Second, we rerun our model using the ordinary least squares (OLS) estimator with standard errors adjusted for heteroskedasticity and clustered at the firm level (specification (2)). The results remain qualitatively similar to our main findings.

Third, we estimate our model using the Fama-MacBeth procedure that estimates cross-sectional regressions separately for each year (specification (3)). The coefficient of OVERALL_VDI continues to be positive and statistically significant. We furthermore employ the Fama-MacBeth estimation with Newey-West standard errors (specification (4)). This approach accounts for serial correlation using a first-order autoregressive process (Haggard et al., 2008). We obtain materially similar results to those previously reported.

Fourth, we conduct our analysis by employing a random effect estimation that takes into account the panel nature of the data (specification (5)). Our finding of a significant and positive association between voluntary disclosure and long-term debt is unchanged.

Fifth, we perform a dynamic generalized method of moments (GMM) estimation that addresses any endogeneity concern by using a set of lagged variables as instruments in our model (specification (6)). The results show that the voluntary disclosure effect on debt maturity is strongly positive at the $1 \%$ statistical level, thus reinforcing the prediction of our first hypothesis. Our GMM model is also well specified. Indeed, the AR(2) second-order serial correlation test yields a $p$-value of 0.649 , meaning that we cannot reject the null hypothesis of no second-order serial correlation. Moreover, the $p$-value of the J-statistic of the Hansen test of overidentification is 0.919 , indicating that we cannot reject the hypothesis that our instruments are valid. 
In summary, the results from Table 7 provide strong evidence that voluntary disclosure plays an important role in determining corporate debt maturity. Its impact on debt maturity is both economically and statistically rigorous. ${ }^{24}$

\section{[Insert Table 7 about here]}

\subsection{Additional analysis}

In additional analysis, we estimate the effect of voluntary disclosure on other mixes of external financing sources having different implications on agency costs. In specification (1) of Table 8, we report the results of estimating the effect of voluntary disclosure on the choice between public debt and private debt. Consistent with a number of studies (e.g., Diamond, 1991; Smith and Warner, 1979), it is argued that private debt has lower agency costs relative to public debt, due to the concentrated ownership of private debt, which increases lenders' incentives to engage in costly monitoring. We find that voluntary disclosure is positively related to public debt, indicating that voluntary disclosure helps bondholders exercise effective monitoring over the firm and could thus substitute for private debt in its monitoring role.

In specification (2) of Table 8, we report the results of estimating the debt-equity choice. It is suggested that, compared to debt, equity is less subject to the scrutiny of the marketplace, thus allowing for higher agency costs (Hovakimian et al. 2001; Jensen and Meckling, 1976). We find that the proportion of equity relative to debt increases with voluntary disclosure, suggesting that such disclosure is more valuable for equityholders in their investment decisions. Indeed, debt already provides debtholders with great potential for management monitoring, thus lowering their reliance on voluntary disclosure to reduce agency costs. In sum, these findings corroborate our main conclusion that capital providers place more weight on voluntary disclosure when their financing produces higher agency costs.

We note that the control variables are roughly the same for public debt and the debtequity choice, i.e., leverage (LEVERAGE), tangibility of assets (TANGIBILITY), profitability $(R O A)$, Market-to-book ratio (MTB), firm size (SIZE), and default risk (Z-SCORE). The signs

\footnotetext{
${ }^{24}$ We also perform a weighted least squares regression to consider the unequal influence of industries on our analysis given their uneven distribution over the sample. We obtain similar results to those found in our main analysis (not tabulated).
} 
of these variables are, overall, consistent with those documented by prior literature such as Flannery and Rangan (2006), Hovakimian et al. (2001), and Kayhan and Titman (2007).

\section{[Insert Table 8 about here]}

\subsection{Endogeneity issues}

While corporate disclosure policy seems to affect the maturity structure of corporate debt, it could in turn, be affected by debt maturity. Indeed, long-term debt allows insiders to insulate themselves from market scrutiny for long periods, leading lenders to require more transparency, notably through comprehensive voluntary disclosure (Milgrom, 1981; Verrecchia, 1983).

Consistent with prior accounting studies including Brown and Hillegeist (2007) and Dhaliwal et al., (2011b) we address this endogeneity by using instrumental variables to replace the proxy for voluntary disclosure with a predicted variable and employ a twostage least squares approach.

In the first stage, we estimate the following regression model:

$G E N \_V D I_{i}=\beta_{0}+I N S T R U M E N T S_{i}+\varepsilon_{i}$

where GEN_VDI is overall voluntary disclosure index, and INSTRUMENTS is a vector of variables that proxy for the costs and benefits of voluntary disclosure. Following prior research, these variables are firm age, analyst following, profitability, market-to-book ratio, performance volatility, market concentration, firm size, equity issuance, and litigation risk. Their definitions are provided in Appendix 2.

Consistent with prior studies, we use firm age (AGE) and analyst following (ANALYST) to proxy for the demand for information. Barton and Waymire (2004) use firm age to proxy for market demand for information about newer firms. AGE is proxied by the natural logarithm of one plus the number of years since incorporation. Lang and Lundholm (1996) show that firms followed by more analysts provide more voluntary disclosure to satisfy analysts' information needs. ${ }^{25}$ ANALYST is measured by the natural logarithm of one plus the number of analysts following during the year. We also include return on assets $(R O A)$ as a determinant for voluntary disclosure since more profitable firms are more willing

${ }^{25}$ Data on analyst following are from the I/B/E/S dataset. We assign 0 for firms that do not appear in the database, following Boubaker and Labégorre (2008). 
to share their good news, implying more voluntary disclosure (Lang and Lundholm, 1993). In addition, we control for market-to-book ratio (MTB) -as a measure for growth opportunities- given that growth opportunities typically increase uncertainty and information asymmetry, leading to greater demand for information. Following Lang and Lundholm (1993), we also control for performance volatility (STD_ROA) because firms with more volatile results are more exposed to legal action, which encourages them to increase their public disclosure. In addition, we introduce market concentration (CONCENTRATION) to the model as a proxy for proprietary costs. Studies, including Bamber and Cheon (1998), show that firms acting in highly concentrated markets disclose more information due to lower proprietary costs. This variable is measured by the Herfindahl-Hirschman index, computed as the sum of the squared market shares based on sales relative to total industry sales, where industry is defined according to Campbell's (1996) industry classification. We also include firm size (SIZE) because large firm may benefit from extensive disclosure to reduce the important contracting costs they are exposed to (Diamond, 1985). Moreover, Lang and Lundholm (2000) show that firms tend to increase their transparency when raising equity to reduce information asymmetry and obtain funds at a lower cost. We thus control for capital issuance (ISSUANCE) by introducing a dummy variable that equals one if the firm issues equity during the current year or the two following years, and 0 otherwise. Lastly, we include litigation risk (LITIGATION) since many studies such as Skinner (1994) show that providing more voluntary disclosure, in particular, of bad news reduces firms' exposure to litigation risk. We proxy for litigation risk using a dummy variable that equals 1 if the firm belongs to a high litigation industry (SIC codes 2833-2836, 3570-3577, 3600-3674, 5200-5961, 7370-7374, 8731-8734), and 0 otherwise.

Table 9 presents the results the two-stage least squares estimation. In specification (3), we estimate the first-stage disclosure model, using the general voluntary disclosure index OVERALL_VDI as dependent variable. The results indicate that our instruments are valid overall, since the estimated coefficients of six of the nine variables are statistically significant and have the predicted sign. The Partial F- statistic in the first-stage regression (specification 3 ) is of 20.2267, which is well above the commonly applied critical value of 10 , meaning that we do not have a weak-instrument problem (Stock and Yogo,2005). 
In specification (1), we estimate the second stage of the 2SLS procedure that uses debt maturity as the dependent variable and introduces the first-stage fitted values for voluntary disclosure. The Wu-Hausman's test for exogeneity exhibits a $p$-value of 0.006 , which strongly rejects the null hypothesis of exogeneity of the variable of interest, i.e., voluntary disclosure, implying that the 2SLS estimate is preferable to the OLS estimator. The results indicate that the voluntary disclosure index has a positive and statistically significant coefficient, which corroborates our main finding of more long-maturity debt in firms with higher voluntary disclosure.

In specification (2), we use a GMM-IV estimation that introduces exogenous variables as instruments in the moment conditions. This technique has the advantage of ensuring that the standard errors of the estimates are heteroskedasticity and autocorrelation consistent. The results are again supportive of the main findings, meaning that our conclusions are not driven by endogeneity issues. The GMM C statistic's test of endogeneity has a $p$-value of 0.000 , thus rejecting the hypothesis that the variable on voluntary disclosure is exogenous. The control variables in the 2SLS estimations have, overall, similar signs and statistical significance as found in the main analysis.

\section{[Insert Table 9 about here]}

\section{Conclusions}

The debt contracting literature suggests that firms are better able to negotiate favorable debt terms when they offer a better information and monitoring environment (e.g., Armstrong et al., 2010; Christensen et al., 2016; Diamond, 1991). This study examines the effect of voluntary disclosure on debt maturity structure using a sample of 2,485 observations of French listed firms over 2007-2013. Our analysis starts with univariate results and continues with a 2SLS regression analysis that accounts for the joint determination of debt maturity and leverage. The results indicate that voluntary disclosure positively affects longterm debt, a finding consistent with the notion that an expanded corporate disclosure policy

allows for better access to long-term debt due to high-disclosure firms having lower information asymmetry and better observability of insider actions.

In firms with concentrated control, controlling shareholders typically have control rights in excess of cash-flow rights, making them inclined to misuse firm resources in the 
pursuit of private benefits (e.g., Bennedsen and Nielsen, 2010; Claessens et al., 2002; Johnson et al., 2000). We thus explore the role of controlling shareholders' excess control rights in shaping the relation between voluntary disclosure and debt maturity. One view suggests that firms with excess control rights offer a poor information environment to obfuscate the selfserving behavior of controlling shareholders, making voluntary disclosure less valuable in obtaining long-term debt. An alternative view indicates that these firms exhibit greater corporate transparency to avoid unfavorable financing conditions, making voluntary disclosure more valuable to lenders.

We provide empirical evidence of a positive association between voluntary disclosure and long-term debt only when the control rights of the controlling shareholders are significantly in excess of cash-flow rights, supporting the view that voluntary disclosure is more valuable when the risk of private benefit extraction by entrenched controlling shareholders is higher. These shareholders could thus gain greater benefits from corporate transparency than from extracting private benefits of control. Our main results persist when we specify alternative measures for debt maturity and excess control rights, as well as alternative sample compositions and statistical techniques. We also address endogeneity issues.

Overall, our evidence implies that voluntary disclosure provides an efficient monitoring mechanism in firms where long-term debt could insulate firms from lender scrutiny for a long time. Our work also supports the findings of recent studies where better disclosure policies are viewed more positively by the market in environments where the risk of wealth expropriation by dominant shareholders is higher. 


\section{References}

Ali, A., Chen, T. Y., \& Radhakrishnan, S. (2007). Corporate disclosures by family firms. Journal of Accounting and Economics, 44, 238-286.

Amir, E., \& Lev, B. (1996). Value-relevance of nonfinancial information: The wireless communications industry. Journal of Accounting and Economics, 22, 3-30.

Armstrong, C.S., Guay, W.R., \& Weber, J.P. (2010). The role of information and financial reporting in corporate governance and debt contracting. Journal of Accounting and Economics, 50, 179-234.

Awartani, B., Belkhir, M., Boubaker, S., \& Maghyereh, A. (2016). Corporate debt maturity in the MENA region: Does institutional quality matter? International Review of Financial Analysis, $46,309-325$.

Bamber, L. S., \& Cheon, Y.S. (1998). Discretionary management earnings forecast disclosures: Antecedents and outcomes associated with forecast venue and forecast specificity choices. Journal of Accounting Research, 36, 167-190.

Barclay, M.J., \& Smith, C.W. (1995). The maturity structure of corporate debt. The Journal of Finance, 50, 609-631.

Barnea, A., Haugen, R.A., \& Senbet, L.W. (1980). A rationale for debt maturity structure and call provisions in the agency theoretic framework. The Journal of Finance, 35, 1223-1234.

Barton, J., \& Waymire, G. (2004). Investor protection under unregulated financial reporting. Journal of Accounting and Economics, 38, 65-116.

Ben-Nasr, H., Boubaker, S., \& Rouatbi, W. (2015). Ownership structure, control contestability, and corporate debt maturity. Journal of Corporate Finance, 35, 265-285.

Bennedsen, M., \& Nielsen, K.M. (2010). Incentive and entrenchment effects in European ownership. Journal of Banking $\mathcal{E}$ Finance, 34, 2212-2229.

Berger, A.N., Espinosa-Vega, M.A., Frame, W.S., \& Miller, N.H. (2005). Debt maturity, risk, and asymmetric information. The Journal of Finance, 60, 2895-2923.

Berglöf, E., \& Pajuste, A. (2005). What do firms disclose and why? Enforcing corporate governance and transparency in Central and Eastern Europe. Oxford Review of Economic Policy, 21, 178-197.

Bharath, S.T., Sunder, J., \& Sunder, S.V. (2008). Accounting quality and debt contracting. The Accounting Review, 83, 1-28.

Billett, M.T., King, T.H.D., \& Mauer, D.C. (2007). Growth opportunities and the choice of leverage, debt maturity, and covenants. The Journal of Finance, 62, 697-730.

Botosan, C.A. (1997). Disclosure level and the cost of equity capital. The Accounting Review, 72, 323-349. 
Boubaker, S. (2007). Ownership-control discrepancy and firm value: Evidence from France. Multinational Finance Journal, 11, 211-252.

Boubaker, S., Derouiche, I., \& Lasfer, M. (2015). Geographic location, excess control rights, and cash holdings. International Review of Financial Analysis, 42, 24-37.

Boubaker, S., \& Labégorre., F. (2008). Ownership structure, corporate governance and analyst following: A study of French listed firms. Journal of Banking \& Finance, 32, 961-976.

Boubakri, N., \& Ghouma, H. (2010). Control/ownership structure, creditor rights protection, and the cost of debt financing: International evidence. Journal of Banking $\mathcal{E}$ Finance, 34, 24812499.

Brown, S., \& Hillegeist, S.A. (2007). How disclosure quality affects the level of information asymmetry. Review of Accounting Studies, 12, 443-477.

Bushman, R.M., \& Smith, A.J. (2001). Financial accounting information and corporate governance. Journal of Accounting and Economics, 32, 237-333.

Campbell, J.Y. (1996). Understanding risk and return. Journal of Political Economy, 104, 298345.

Charumilind, C., Kali, R., \& Wiwattanakantang, Y. (2006). Connected lending: Thailand before the financial crisis. The Journal of Business, 79, 181-218.

Chau, G. K., \& Gray, S. J. (2002). Ownership structure and corporate voluntary disclosure in Hong Kong and Singapore. The International Journal of Accounting, 37, 247-265.

Chau, G., \& Gray, S.J. (2010). Family ownership, board independence and voluntary disclosure: Evidence from Hong Kong. Journal of International Accounting, Auditing and Taxation, 19, 93-109.

Chen, T.Y., Dasgupta, S., \& Yu, Y. (2014). Transparency and financing choices of family firms. Journal of Financial and Quantitative Analysis, 49, 381-408.

Christensen, H.B., Nikolaev, V.V., \& Wittenberg-Moerman, R. (2016). Accounting information in financial contracting: The incomplete contract theory perspective. Journal of Accounting Research, 54, 397-435.

Chung, H., Judge, W.Q., \& Li, Y.H. (2015). Voluntary disclosure, excess executive compensation, and firm value. Journal of Corporate Finance, 32, 64-90.

Claessens, S., Djankov, S., \& Lang, L.H. (2000). The separation of ownership and control in East Asian corporations. Journal of Financial Economics, 58, 81-112.

Claessens, S., Djankov, S., Fan, J.P., \& Lang, L.H. (2002). Disentangling the incentive and entrenchment effects of large shareholdings. The Journal of Finance, 57, 2741-2771.

Cole, R.A. (1998). The importance of relationships to the availability of credit. Journal of Banking \& Finance, 22, 959-977.

Cronbach, L. J. (1951). Coefficient alpha and the internal structure of tests. psychometrika, 16, 297-334. 
Datta, S., Iskandar-Datta, M.A.I., \& Raman, K. (2005). Managerial stock ownership and the maturity structure of corporate debt. The Journal of Finance, 60, 2333-2350.

Davydenko, S.A., \& Franks, J.R. (2008). Do bankruptcy codes matter? A study of defaults in France, Germany, and the UK. The Journal of Finance, 63, 565-608.

Dhaliwal, D.S., Li, O.Z., Tsang, A., \& Yang, Y.G. (2011a). Voluntary nonfinancial disclosure and the cost of equity capital: The initiation of corporate social responsibility reporting. The Accounting Review, 86, 59-100.

Dhaliwal, D.S., Khurana, I.K., \& Pereira, R. (2011b). Firm disclosure policy and the choice between private and public debt. Contemporary Accounting Research, 28, 293-330.

Diamond, D. W. (1985). Optimal release of information by firms. The Journal of Finance, 40, 1071-1094.

Diamond, D.W. (1991). Debt maturity structure and liquidity risk. The Quarterly Journal of Economics, 106, 709-737.

Djankov, S., La Porta, R., Lopez-de-Silanes, F., \& Shleifer, A. (2008). The law and economics of self-dealing. Journal of Financial Economics, 88, 430-465.

Donnelly, R., \& Mulcahy, M. (2008). Board structure, ownership, and voluntary disclosure in Ireland. Corporate Governance: An International Review, 16, 416-429

Easley, D., \& O'Hara, M. (2004). Information and the cost of capital. The Journal of Finance, 59, 1553-1583.

El Ghoul, S., Guedhami, O., Pittman, J.A., \& Rizeanu, S. (2016). Cross-country evidence on the importance of auditor choice to corporate debt maturity. Contemporary Accounting Research, 33, 718-751

Eng, L.L., \& Mak, Y.T. (2003). Corporate governance and voluntary disclosure. Journal of Accounting and Public Policy, 22, 325-345.

Faccio, M., \& Lang, L.H. (2002). The ultimate ownership of Western European corporations. Journal of Financial Economics, 65, 365-395.

Fang, J., Pittman, J., Zhang, Y., \& Zhao, Y. (2017). Auditor choice and its implications for group-affiliated firms. Contemporary Accounting Research, 34, 39-82.

Flannery, M. J., \& Rangan, K. P. (2006). Partial adjustment toward target capital structures. Journal of Financial Economics, 79, 469-506.

Francis, J., Nanda, D., \& Olsson, P. (2008). Voluntary disclosure, earnings quality, and cost of capital. Journal of Accounting Research, 46, 53-99.

García-Teruel, P.J., Martínez-Solano, P., \& Sánchez-Ballesta, J.P. (2010). Accruals quality and debt maturity structure. Abacus, 46, 188-210.

Godlewski, C. J. (2015). The dynamics of bank debt renegotiation in Europe: A survival analysis approach. Economic Modelling, 49, 19-31. 
Guedhami, O., Pittman, J. A., \& Saffar, W. (2009). Auditor choice in privatized firms: Empirical evidence on the role of state and foreign owners. Journal of Accounting and Economics, 48, 151-171.

Gul, F.A., \& Leung, S. (2004). Board leadership, outside directors' expertise and voluntary corporate disclosures. Journal of Accounting and Public Policy, 23, 351-379.

Haggard, K.S., Martin, X., \& Pereira, R. (2008). Does voluntary disclosure improve stock price informativeness? Financial Management, 37, 747-768.

Harford, J., Li, K., \& Zhao, X. (2008). Corporate boards and the leverage and debt maturity choices. International Journal of Corporate Governance, 1, 3-27.

Healy, P.M., \& Palepu, K.G. (2001). Information asymmetry, corporate disclosure, and the capital markets: A review of the empirical disclosure literature. Journal of Accounting and Economics, 31, 405-440.

Hermalin, B.E., \& Weisbach, M.S. (2012). Information disclosure and corporate governance. The Journal of Finance, 67, 195-233.

Hong, H.A. (2013). Does mandatory adoption of international financial reporting standards decrease the voting premium for dual-class shares? The Accounting Review, 88, 1289-1325.

Hovakimian, A., Opler, T., \& Titman, S. (2001). The debt-equity choice. Journal of Financial and Quantitative analysis, 36, 1-24.

Jankensgård, H. (2018). Between a rock and a hard place: New evidence on the relationship between ownership and voluntary disclosure. International Review of Financial Analysis, 56, 281-291.

Jensen, M.C., \& Meckling, W.H. (1976). Theory of the firm: Managerial behavior, agency costs and ownership structure. Journal of Financial Economics, 3, 305-360.

Jiang, W., Li, K., \& Shao, P. (2010). When shareholders are creditors: Effects of the simultaneous holding of equity and debt by non-commercial banking institutions. The Review of Financial Studies, 23, 3595-3637.

Johnson, S., La Porta, R.F., Lopez-de-Silanes, F., \& Shleifer, A. (2000). Tunneling. American Economic Review Papers \& Proceedings, 90, 22-27.

Kasznik, R., \& Lev, B. (1995). To warn or not to warn: Management disclosures in the face of an earnings surprise. Accounting Review, 70, 113-134.

Kayhan, A., \& Titman, S. (2007). Firms' histories and their capital structures. Journal of financial Economics, 83, 1-32.

Khlif, H., Ahmed, K., \& Souissi, M. (2017). Ownership structure and voluntary disclosure: A synthesis of empirical studies. Australian Journal of Management, 42, 376-403.

Kirch, G., \& Terra, P.R.S. (2012). Determinants of corporate debt maturity in South America: Do institutional quality and financial development matter? Journal of Corporate Finance, 18, 980-993. 
Laksmana, I. (2008). Corporate board governance and voluntary disclosure of executive compensation practices. Contemporary Accounting Research, 25, 1147-1182.

Lang, M., \& Lundholm, R. (1993). Cross-sectional determinants of analyst ratings of corporate disclosures. Journal of Accounting Research, 31, 246-271.

Lang, M. H., \& Lundholm, R. J. (1996). Corporate disclosure policy and analyst behavior. Accounting review, 467-492.

Lang, M.H., \& Lundholm, R.J. (2000). Voluntary disclosure and equity offerings: Reducing information asymmetry or hyping the stock? Contemporary Accounting Research, 17, 623-662.

Lannoo, K. (1999). A European perspective on corporate governance. JCMS: Journal of Common Market Studies, 37, 269-294.

La Porta, R., Lopez-de-Silanes, F., Shleifer, A., \& Vishny, R.W. (1997). Legal determinants of external finance. The Journal of Finance, 52, 1131-1150.

La Porta, R., Lopez-de-Silanes, F., \& Shleifer, A. (1999). Corporate ownership around the world. The Journal of Finance, 54, 471-517.

La Porta, R., Lopez-de-Silanes, F., Shleifer, A., \& Vishny, R. (2002). Investor protection and corporate valuation. The Journal of Finance, 57, 1147-1170.

La Porta, R., Lopez-de-Silanes, F., \& Zamarripa, G. (2003). Related lending. The Quarterly Journal of Economics, 118, 231-268.

Lin, C., Ma, Y., Malatesta, P., \& Xuan, Y. (2011). Ownership structure and the cost of corporate borrowing. Journal of Financial Economics, 100, 1-23.

Li, F. (2008). Annual report readability, current earnings, and earnings persistence. Journal of Accounting and Economics, 45, 221-247.

Luo, S., Courtenay, S. M., \& Hossain, M. (2006). The effect of voluntary disclosure, ownership structure and proprietary cost on the return-future earnings relation. Pacific-Basin Finance Journal, 14, 501-521.

Mazumdar, S.C., \& Sengupta, P. (2005). Disclosure and the loan spread on private debt. Financial Analysts Journal, 61, 83-95.

Meek, G.K., Roberts, C.B., \& Gray, S.J. (1995). Factors influencing voluntary annual report disclosures by US, UK and continental European multinational corporations. Journal of International Business Studies, 26, 555-572.

Melis, A., Gaia, S., \& Carta, S. (2015). Directors' remuneration: A comparison of Italian and UK non-financial listed firms' disclosure. The British Accounting Review, 47, 66-84.

Meng, X.H., Zeng, S.X., Tam, C.M., \& Xu, X.D. (2013). Whether top executives' turnover influences environmental responsibility: From the perspective of environmental information disclosure. Journal of Business Ethics, 114, 341-353.

Milgrom, P.R. (1981). Good news and bad news: Representation theorems and applications. The Bell Journal of Economics, 12, 380-391. 
Morris, R.D., Pham, T., \& Gray, S.J. (2011). The value relevance of transparency and corporate governance in Malaysia before and after the Asian financial crisis. Abacus, 47, 205-233.

Myers, S.C. (1977). Determinants of corporate borrowing. Journal of Financial Economics, 5, $147-175$.

Östberg, P. (2006). Disclosure, investment and regulation. Journal of Financial Intermediation, 15, 285-306.

Roberts, M.R., \& Sufi, A. (2009). Renegotiation of financial contracts: Evidence from private credit agreements. Journal of Financial Economics, 93, 159-184.

Shleifer, A., \& Vishny, R. (2011). Fire sales in finance and macroeconomics. Journal of

Economic Perspectives, 25, 29-48.

Skinner, D. J. (1994). Why firms voluntarily disclose bad news. Journal of accounting research, 32, 38-60.

Smith Jr, C. W., \& Warner, J. B. (1979). On financial contracting: An analysis of bond covenants. Journal of Financial Economics, 7, 117-161.

Stock, J. H., \& Yogo, M. (2005). Testing for weak instruments in linear IV regression. Chapter 5 in Identification and Inference in Econometric Models: Essays in Honor of Thomas J. Rothenberg, edited by DWK Andrews and JH Stock.

Verrecchia, R.E. (1983). Discretionary disclosure. Journal of Accounting and Economics, 5, 179194.

Verrecchia, R.E. (2001). Essays on disclosure. Journal of Accounting and Economics, 32, 97-180.

Zheng, X., El Ghoul, S., Guedhami, O., \& Kwok, C.C. (2012). National culture and corporate debt maturity. Journal of Banking \& Finance, 36, 468-488. 


\section{Appendix 1. Voluntary disclosure checklist}

Items of content

A-General corporate information

- Brief history

D, E

- Organizational structure/Chart

$\mathrm{D}, \mathrm{E}$

- Description of products/services

$\mathrm{A}, \mathrm{B}, \mathrm{C}$

- Main markets

- Market share of key products

$\mathrm{A}, \mathrm{B}, \mathrm{C}$,

$\mathrm{A}, \mathrm{B}, \mathrm{C}, \mathrm{D}$,

- Statement of general objectives

$\mathrm{A}, \mathrm{B}, \mathrm{C}, \mathrm{D}, \mathrm{E}$

- Statement of financial objectives

$\mathrm{B}, \mathrm{D}, \mathrm{E}$

- Annual report in English

B-Information on corporate governance

B1-Insiders (Shareholders and managers)

- Identity of principal shareholders

B, D, E

- Ownership of principal shareholders

$\mathrm{B}, \mathrm{D}, \mathrm{E}$

- Votes of principal shareholders

B, D, E

- Draft resolution of shareholders' meetings

$\mathrm{B}$

- List of senior managers (not sitting on the board of directors)

B, E,

- Picture of senior managers

$\mathrm{B}, \mathrm{E}$,

- Personal profile of managers

$\mathrm{B}, \mathrm{E}$,

- Age of senior managers

B, E,

- Number of shares owned by managers

B, E, F

- Number of votes owned by managers

B, E, F

- Basis for determining managers' remuneration

B, E, F

- Weight assigned on managers' performance measures

$\mathrm{B}, \mathrm{F}$

- Discussion of the decision-making process of managers

B, F

- Form of managers' remuneration (cash, shares, etc.)

B, F

B, F

B2-Other corporate governance characteristics

- List of directors

$\mathrm{B}, \quad \mathrm{E}$

- Picture of directors

B, E

- Description of the role of the board

$\mathrm{B}, \mathrm{E}$

- Significant issues addressed by the board during the year

B, E

- Frequency and dates of board meetings

B

- Attendance of directors at board meetings

B

- Independence of directors

B

- Personal profile of directors

B, D

- Age of directors

B, D

- Date of first appointment of directors

B

- Start of current term/renewal of directors

B

- End of current term of directors

B

- Number of shares held by the directors

B, D

- Number of votes held by the directors

B D 
- Information about the directors dealing

B, D

- Existence of a compensation committee

B

- Role and functioning of the compensation committee

B

- Significant issues addressed by the compensation committee B

- The name of the compensation committee members B

- Number of compensation committee meetings during the year $\quad B$

- Attendance at compensation committee meetings B

- Existence of an audit committee B

- Role and functioning of the audit committee B

- Significant issues addressed by the audit committee during the B

- Names of the audit committee members B

- Number of audit committee meetings during the year B

- Attendance at audit committee meetings B

- Reference to a code of best practices B

- Date of first appointment of current auditors B

- Expiration date of term of current auditors B

- Renewal of terms of current auditors B

- Auditors' fees

C-Financial information

- Financial statements of the past two years

- Turnover of the past two years

- Sales of key products

- Summary of financial data of the previous years

- Summary of key ratios over at least three years

- Dividend policy

- Earnings per share

$\mathrm{D}, \mathrm{E}$

- Financial calendar

A, B, C, D, E

$\mathrm{D}, \mathrm{E}$

$\mathrm{A}, \mathrm{B}, \mathrm{C}, \mathrm{D}, \mathrm{E}$

A, B, C, D, E

$\mathrm{D}, \mathrm{E}$

D, E

C, D

- Historical share prices

C, D, E

- Share price by the end of the year

$\mathrm{A}, \mathrm{C}, \mathrm{D}, \mathrm{E}$

- Share prices trend

- Stock price performance in relation to stock market index

$\mathrm{A}, \mathrm{C}, \mathrm{D}, \mathrm{E}$

$\mathrm{A}, \mathrm{C}, \mathrm{D}, \mathrm{E}$

- Market capitalization by the end of the year

$\mathrm{A}, \mathrm{C}, \mathrm{D}, \mathrm{E}$

- Trend of market capitalization

$\mathrm{A}, \mathrm{C}, \mathrm{D}, \mathrm{E}$

- Sales forecast

$\mathrm{A}, \mathrm{B}, \mathrm{C}, \mathrm{D}, \mathrm{E}$

- Forecasted market share

$\mathrm{A}, \mathrm{B}, \mathrm{C}, \mathrm{D}, \mathrm{E}$

- Cash flow/Turnover forecast

$\mathrm{A}, \mathrm{B}, \mathrm{C}, \mathrm{D}, \mathrm{E}$

- Earnings estimates

$\mathrm{A}, \mathrm{B}, \mathrm{C}, \mathrm{D}, \mathrm{E}$

A: Botasan (1997)

B : Ali et al., (2007)

C: Francis et al., (2007)

D : Meek et al,. (1995)

E : Chau and Gray (2002)

F : Laksama (2008) 
Appendix 2. Variable definitions and sources

\begin{tabular}{|c|c|c|}
\hline Variable & Definition & Source \\
\hline \multicolumn{3}{|c|}{ Voluntary disclosure variables } \\
\hline OVERALL_VDI & Overall voluntary disclosure index (all items) & $\begin{array}{l}\text { Annual } \\
\text { reports and } \\
\text { authors' } \\
\text { calculations }\end{array}$ \\
\hline GOV_VDI & $\begin{array}{l}\text { Governance voluntary disclosure index (items of corporate } \\
\text { governance characteristics) }\end{array}$ & As above \\
\hline$I N S_{-} V D I$ & $\begin{array}{l}\text { Insiders' voluntary disclosure index (items of managers and } \\
\text { controlling shareholders characteristics) }\end{array}$ & As above \\
\hline$F I N \_V D I$ & $\begin{array}{l}\text { Financial voluntary disclosure index (items of financial } \\
\text { information) }\end{array}$ & As above \\
\hline \multicolumn{3}{|c|}{ Excess control variables } \\
\hline EXCESS & $\begin{array}{l}\text { Excess control rights of the controlling shareholder } \\
\text { (considering the } 10 \% \text { control level), computed as the } \\
\text { difference between the controlling shareholder's control } \\
\text { rights and cash-flow rights, divided by the controlling } \\
\text { shareholder's control rights, where (i) control rights are } \\
\text { computed as the sum of the weakest links of voting rights } \\
\text { along each control chain and (ii) cash-flow rights are } \\
\text { measured as the sum of the products of ownership stakes } \\
\text { along the different control chains }\end{array}$ & As above \\
\hline EXCESS_RATIO & $\begin{array}{l}\text { A measure of excess control rights of the controlling } \\
\text { shareholder, computed as the ratio of the controlling } \\
\text { shareholder's control rights to cash-flow rights }\end{array}$ & As above \\
\hline EXCESS_DIFF & $\begin{array}{l}\text { A measure of excess control rights of the controlling } \\
\text { shareholder, computed as the difference between the } \\
\text { controlling shareholder's control rights and cash-flow rights }\end{array}$ & As above \\
\hline EXCESS20 & $\begin{array}{l}\text { Excess control rights of the controlling shareholder for the } \\
20 \% \text { control level, computed as the difference between the } \\
\text { controlling shareholder's control rights and cash-flow rights, } \\
\text { divided by the controlling shareholder's control rights }\end{array}$ & As above \\
\hline \multicolumn{3}{|c|}{ Main financial variables } \\
\hline DEBT_MATURITY & $\begin{array}{l}\text { Debt maturity, computed as the ratio of long-term debt to } \\
\text { total debt }\end{array}$ & $\begin{array}{l}\text { Worldscope } \\
\text { and authors' } \\
\text { calculations }\end{array}$ \\
\hline LEVERAGE & $\begin{array}{l}\text { Firm leverage, computed as the ratio of total debt to total } \\
\text { assets }\end{array}$ & As above \\
\hline $\begin{array}{l}\text { ASSET_MATURIT } \\
Y\end{array}$ & $\begin{array}{l}\text { Asset maturity, measured as the weighted average of the } \\
\text { maturities of current and long-term assets, where the } \\
\text { maturity of current assets is current assets divided by the } \\
\text { cost of goods sold and the maturity of long-term assets is the } \\
\text { ratio of gross plant, property and equipment to depreciation } \\
\text { and amortization }\end{array}$ & As above \\
\hline
\end{tabular}


STD_ROA

ABNE

SIZE

Additional variables

DEBT_MATURITY

DUMMY

DEBT_MATURITY

1

$P P E$

$R O A$

REGULATED

AGE

CONCENTRATION

ISSUANCE

LITIGATION

TANGIBILITY

Z_SCORE

Equity to debt
Performance variability, computed as the standard deviation of a firm's return on assets over the previous five years Firm abnormal earnings, computed as the change in EBITDA from year $t$ to year $t+1$, divided by the market value of equity in year $t$

Firm size computed as the natural logarithm of total assets (in thousands of euros)

A dummy measure of debt maturity that equals 1 when the the ratio of long-term debt to total debt exceeds $50 \%$, and 0 otherwise

A measure of debt maturity that is the difference between total liabilities and current liabilities, divided by total liabilities

Ratio of net plant, property and equipment to total assets Profitability, measured as return on assets

A dummy variable that equals 1 if the firm belongs to a regulated industry, and 0 otherwise, where regulated industries comprise sectors such as railroads (SIC code 4011), trucking (SIC codes 4210, 4213), airlines (SIC code 4512), and telecommunications (SIC codes 4812, 4813)

Firm age, measured as the natural logarithm of one plus the number of year since incorporation

Market concentration, proxied by the Herfindahl-Hirschman index, computed as the sum of the squared market shares based on sales relative to total industry sales, where industry is defined according to Campbell's (1996) industry classification

Equity issuance, a dummy variable that equals 1 if the firm issues equity during the current year or the two following years, and 0 otherwise A dummy variable that equals 1 if the firm belongs to a high litigation industry (SIC codes 2833-2836, 3570-3577, 36003674, 5200-5961, 7370-7374, 8731-8734), and 0 otherwise Ratio of net plant, property and equipment to total assets Altman's (1968) Z-score, calculated as follows: $\left(1.2^{*}\right.$ working capital $+1.4^{*}$ retained earnings $+3.3^{*}$ earnings before interest and taxes $+0.999^{*}$ sales $) /$ total assets $+0.6^{*}$ (market value of equity/book value of debt)

Ratio of equity to total debt
As above

As above

As above

As above

As above

As above As above

As above

As above

As above

As above

As above

As above

As above

As above 
ANALYST

Public debt
Number of analysts following a firm, computed as the natural logarithm of one plus the number of analysts following during the year

Ratio of public debt to total debt
$\mathrm{I} / \mathrm{B} / \mathrm{E} / \mathrm{S}$

dataset

Capital IQ

dataset 
Table 1

Descriptive statistics

\begin{tabular}{|c|c|c|c|c|c|c|c|}
\hline \multicolumn{8}{|c|}{ Panel A: Variables in the main analysis } \\
\hline Variable & Mean & $\begin{array}{l}\text { Standard } \\
\text { deviation }\end{array}$ & Minimum & $\begin{array}{l}25 \text { th } \\
\text { percentile }\end{array}$ & Median & $\begin{array}{l}\text { 75th } \\
\text { percentile }\end{array}$ & Maximum \\
\hline OVERALL_VDI & 0.4072 & 0.1967 & 0 & 0.2656 & 0.4354 & 0.5593 & 0.7722 \\
\hline GOV_VDI & 0.4971 & 0.1607 & 0 & 0.4444 & 0.5555 & 0.5555 & 0.8888 \\
\hline INS_VDI & 0.5911 & 0.2469 & 0 & 0.4375 & 0.5625 & 0.6875 & 0.9112 \\
\hline FIN-VDI & 0.3292 & 0.1854 & 0 & 0.1831 & 0.3663 & 0.4273 & 0.7792 \\
\hline EXCESS & 0.2229 & 0.2177 & 0 & 0.0146 & 0.2039 & 0.3447 & 0.9585 \\
\hline DEBT_MATURITY & 0.5573 & 0.3036 & 0 & 0.3392 & 0.6122 & 0.7844 & 0.9858 \\
\hline LEVERAGE & 0.2105 & 0.1757 & 0 & 0.0735 & 0.1791 & 0.3045 & 0.9121 \\
\hline ASSET_MATURITY & 5.0437 & 5.3819 & 0 & 0.6843 & 2.5546 & 8.4136 & 18.2011 \\
\hline MTB & 1.8205 & 2.65482 & 0.0308 & 0.3338 & 0.6333 & 1.5470 & 7.5362 \\
\hline STD_ROA & 0.0703 & 0.0980 & 0 & 0.0154 & 0.0322 & 0.0742 & 0.3921 \\
\hline ABNE & 0.0692 & 0.1530 & -0.0999 & -0.0278 & 0.0074 & 0.0869 & 0.452 \\
\hline SIZE & 14.8344 & 4.0512 & 7.1561 & 11.209 & 14.1688 & 18.0128 & 26.2605 \\
\hline \multicolumn{8}{|c|}{ Panel B: Mean of variables of interest by year } \\
\hline Variable & 2007 & 2008 & 2009 & 2010 & 2011 & 2012 & 2013 \\
\hline OVERALL_VDI & 0.3903 & 0.3909 & 0.4121 & 0.4122 & 0.4138 & 0.4147 & 0.4162 \\
\hline GOV_VDI & 0.4960 & 0.4969 & 0.4979 & 0.5001 & 0.4939 & 0.4962 & 0.4989 \\
\hline INS_VDI & 0.5866 & 0.5877 & 0.5906 & 0.5933 & 0.5917 & 0.5924 & 0.5967 \\
\hline FIN-VDI & 0.3187 & 0.3199 & 0.3296 & 0.3300 & 0.3322 & 0.3349 & 0.3394 \\
\hline EXCESS & 0.2324 & 0.2276 & 0.2275 & 0.2250 & 0.2209 & 0.2149 & 0.2091 \\
\hline DEBT_MATURITY & 0.5560 & 0.5538 & 0.5609 & 0.5720 & 0.5487 & 0.5547 & 0.5544 \\
\hline
\end{tabular}

This table reports descriptive statistics. Panel A describes the variables used in our main analysis.

Panel B provide the mean of variables of interest by year. The sample comprises 2,485 firm-year observations representing 440 French listed firms from 2007 to 2013 . All the variables in the table are defined in Appendix 2. 
Table 2

Univariate tests for differences in debt maturity

\begin{tabular}{llllllllll}
\hline & Year & 2007 & 2008 & 2009 & 2010 & 2011 & 2012 & 2013 & $2007-$ \\
Variable & & & & & & & & & 2013 \\
\cline { 3 - 9 } & & Mean & Mean & Mean & Mean & Mean & Mean & Mean & Mean \\
\hline OVERALL_VDI & Below median & 0.5032 & 0.5027 & 0.5068 & 0.5080 & 0.4922 & 0.5095 & 0.5135 & 0.5049 \\
& Above median & 0.6447 & 0.6381 & 0.6219 & 0.6450 & 0.6170 & 0.6094 & 0.6057 & 0.6260 \\
\multirow{2}{*}{ GOV_VDI } & t-Test & $-4.6514^{\mathrm{a}}$ & $-4.4189^{\mathrm{a}}$ & $-3.7953^{\mathrm{a}}$ & $-4.5196^{\mathrm{a}}$ & $-3.7809^{\mathrm{a}}$ & $-2.8826^{\mathrm{a}}$ & $-3.9286^{\mathrm{a}}$ & $-10.0433^{\mathrm{a}}$ \\
& Below median & 0.4884 & 0.4961 & 0.4967 & 0.5100 & 0.4955 & 0.4991 & 0.4941 & 0.4969 \\
& Above median & 0.6156 & 0.6034 & 0.6130 & 0.6200 & 0.5964 & 0.6017 & 0.6018 & 0.6077 \\
\multirow{3}{*}{ INS_VDI } & t-Test & $-4.2957^{\mathrm{a}}$ & $-3.5681^{\mathrm{a}}$ & $-3.8188^{\mathrm{a}}$ & $-3.5668^{\mathrm{a}}$ & $-3.0428^{\mathrm{a}}$ & $-2.9654^{\mathrm{a}}$ & $-3.0394^{\mathrm{a}}$ & $-9.2124^{\mathrm{a}}$ \\
& Below median & 0.5286 & 0.5283 & 0.5373 & 0.5318 & 0.5220 & 0.5177 & 0.4784 & 0.5222 \\
& Above median & 0.6773 & 0.6597 & 0.6438 & 0.7000 & 0.6238 & 0.6393 & 0.6390 & 0.6537 \\
\multirow{2}{*}{ FIN_VDI } & $t$-Test & $-3.8840^{\mathrm{a}}$ & $-3.4644^{\mathrm{a}}$ & $-2.8946^{\mathrm{a}}$ & $-4.6147^{\mathrm{a}}$ & $-2.6507^{\mathrm{a}}$ & $-3.0568^{\mathrm{a}}$ & $-4.0890^{\mathrm{a}}$ & $-9.1591^{\mathrm{a}}$ \\
& Below median & 0.5471 & 0.5301 & 0.5252 & 0.5338 & 0.5180 & 0.4985 & 0.4747 & 0.5197 \\
& Above median & 0.5641 & 0.5746 & 0.5925 & 0.6012 & 0.5749 & 0.5941 & 0.5645 & 0.5808 \\
& $t$-Test & -0.5619 & -1.4615 & $-2.1904^{\mathrm{b}}$ & $-2.1745^{\mathrm{b}}$ & $-1.7005^{\mathrm{c}}$ & $-2.7616^{\mathrm{a}}$ & $-2.5275^{\mathrm{b}}$ & $-5.0283^{\mathrm{a}}$ \\
\hline
\end{tabular}

This table reports the results of pairwise comparisons of the means of debt maturity for groups of firms with a voluntary disclosure index below and above its median value, respectively, by year and for the entire period, using $t$-tests of the means. The sample comprises 2,485 firm-year observations representing 440 French listed firms over the period 2007-2013. All the variables in the table are defined in Appendix 2. The superscripts a, b, and c denote statistical significance at the $1 \%, 5 \%$, and $10 \%$ levels, respectively. The $p$-values of the $t$-test and median tests of equality are reported in parentheses. 
Table 3

Voluntary disclosure and debt maturity

\begin{tabular}{|c|c|c|c|c|}
\hline & (1) & (2) & (3) & $(4)$ \\
\hline OVERALL_VDI & $\begin{array}{l}0.3189 \\
(5.68)^{\mathrm{a}}\end{array}$ & & & \\
\hline GOV_VDI & & $\begin{array}{l}0.2307 \\
(5.37)^{\mathrm{a}}\end{array}$ & & \\
\hline INS_VDI & & & $\begin{array}{l}0.1277 \\
(5.20)^{\mathrm{a}}\end{array}$ & \\
\hline FIN_VDI & & & & $\begin{array}{l}0.1041 \\
(4.42)^{\mathrm{a}}\end{array}$ \\
\hline LEVERAGE & $\begin{array}{l}0.6113 \\
(3.20)^{\mathrm{a}}\end{array}$ & $\begin{array}{l}0.6002 \\
(3.15)^{\mathrm{a}}\end{array}$ & $\begin{array}{l}0.5693 \\
(2.97)^{\mathrm{a}}\end{array}$ & $\begin{array}{l}0.5464 \\
(2.83)^{\mathrm{a}}\end{array}$ \\
\hline ASSET_MATURITY & $\begin{array}{l}0.0031 \\
(2.04)^{b}\end{array}$ & $\begin{array}{l}0.0032 \\
(2.07)^{\mathrm{b}}\end{array}$ & $\begin{array}{l}0.0034 \\
(2.21)^{\mathrm{b}}\end{array}$ & $\begin{array}{l}0.0031 \\
(2.07)^{\mathrm{b}}\end{array}$ \\
\hline MTB & $\begin{array}{l}-0.0031 \\
(-1.18)\end{array}$ & $\begin{array}{l}-0.0031 \\
(-1.21)\end{array}$ & $\begin{array}{l}-0.0038 \\
(-1.45)\end{array}$ & $\begin{array}{l}-0.0033 \\
(-1.28)\end{array}$ \\
\hline STD_ROA & $\begin{array}{l}-0.1650 \\
(-2.76)^{a}\end{array}$ & $\begin{array}{l}-0.1614 \\
(-2.70)^{a}\end{array}$ & $\begin{array}{l}-0.1721 \\
(-2.89)^{a}\end{array}$ & $\begin{array}{l}-0.1691 \\
(-2.84)^{a}\end{array}$ \\
\hline ABNE & $\begin{array}{l}-0.1445 \\
(-2.86)^{a}\end{array}$ & $\begin{array}{l}-0.1458 \\
(-2.89)^{\mathrm{a}}\end{array}$ & $\begin{array}{l}-0.1455 \\
(-2.89)^{\mathrm{a}}\end{array}$ & $\begin{array}{l}-0.1468 \\
(-2.92)^{a}\end{array}$ \\
\hline SIZE & $\begin{array}{l}0.0228 \\
(6.61)^{\mathrm{a}}\end{array}$ & $\begin{array}{l}0.0252 \\
(7.73)^{\mathrm{a}}\end{array}$ & $\begin{array}{l}0.0322 \\
(9.90)^{\mathrm{a}}\end{array}$ & $\begin{array}{l}0.03165 \\
(9.74)^{\mathrm{a}}\end{array}$ \\
\hline Constant & $\begin{array}{l}0.0697 \\
(0.81)\end{array}$ & $\begin{array}{l}0.0653 \\
(0.76)\end{array}$ & $\begin{array}{l}0.0596 \\
(0.69)\end{array}$ & $\begin{array}{l}0.0767 \\
(0.89)\end{array}$ \\
\hline Year dummies & Yes & Yes & Yes & Yes \\
\hline Industry dummies & Yes & Yes & Yes & Yes \\
\hline Number of observations & 2,485 & 2,485 & 2,485 & 2,485 \\
\hline $\mathrm{R}^{2}$ & $12.56 \%$ & $12.73 \%$ & $13.01 \%$ & $13.04 \%$ \\
\hline
\end{tabular}

This table reports the results from a 2SLS estimation of the effect of voluntary disclosure on debt maturity. In all specifications, the dependent variable is debt maturity, DEBT_MATURITY, computed as the ratio of long-term debt to total debt. The sample comprises 2,485 firm-year observations representing 440 French listed firms over the period 2007-2013. All the variables in the table are defined in Appendix 2. Year dummies and industry dummies following Campbell's (1996) classification are included in all the regressions. The $z$-statistics are reported in parentheses. The superscripts a, b, and c denote statistical significance at the $1 \%, 5 \%$, and $10 \%$ levels, respectively. 
Table 4

Excess control rights, voluntary disclosure, and debt maturity

\begin{tabular}{|c|c|c|c|c|c|c|c|c|}
\hline Variable & $\begin{array}{c}\text { Low } \\
\text { EXCESS } \\
(1)\end{array}$ & $\begin{array}{c}\text { High } \\
\text { EXCESS } \\
(2)\end{array}$ & $\begin{array}{c}\text { Low } \\
\text { EXCESS } \\
\text { (3) }\end{array}$ & $\begin{array}{c}\text { High } \\
\text { EXCESS } \\
(4)\end{array}$ & $\begin{array}{c}\text { Low } \\
\text { EXCESS } \\
(5)\end{array}$ & $\begin{array}{c}\text { High } \\
\text { EXCESS } \\
(6)\end{array}$ & $\begin{array}{c}\text { Low } \\
\text { EXCESS } \\
(7)\end{array}$ & $\begin{array}{c}\text { High } \\
\text { EXCESS } \\
(8)\end{array}$ \\
\hline \multirow[t]{2}{*}{ OVERALL_VDI } & 0.0956 & 0.4959 & & & & & & \\
\hline & $(0.99)$ & $(6.27)^{\mathrm{a}}$ & & & & & & \\
\hline \multirow[t]{2}{*}{ GOV_VDI } & & & 0.0853 & 0.3407 & & & & \\
\hline & & & $(1.12)$ & $(5.99)^{a}$ & & & & \\
\hline \multirow[t]{2}{*}{ INS_VDI } & & & & & 0.0113 & 0.2061 & & \\
\hline & & & & & $(0.31)$ & $(5.69)^{a}$ & & \\
\hline \multirow[t]{2}{*}{ FIN_VDI } & & & & & & & 0.0037 & 0.1800 \\
\hline & & & & & & & $(0.11)$ & $(5.28)^{\mathrm{a}}$ \\
\hline \multirow[t]{2}{*}{ LEVERAGE } & 0.6463 & 0.7521 & 0.6613 & 0.7084 & 0.6478 & 0.5746 & 0.6436 & 0.5492 \\
\hline & $(1.93)^{c}$ & $(3.06)^{\mathrm{a}}$ & $(1.98)^{\mathrm{b}}$ & $(2.93)^{a}$ & $(1.97)^{\mathrm{b}}$ & $(2.37)^{b}$ & $(1.92)^{c}$ & $(2.28)^{b}$ \\
\hline \multirow[t]{2}{*}{ ASSET_MATURITY } & 0.0050 & -0.0007 & 0.0051 & -0.0007 & 0.0050 & 0.0003 & 0.0050 & -0.0000 \\
\hline & $(2.53)^{\mathrm{b}}$ & $(-0.31)$ & $(2.51)^{\mathrm{b}}$ & $(-0.28)$ & $(2.53)^{b}$ & $(0.15)$ & $(2.52)^{\mathrm{b}}$ & $(-0.03)$ \\
\hline \multirow[t]{2}{*}{ MTB } & 0.0054 & -0.0102 & 0.0053 & -0.0101 & 0.0052 & -0.0100 & 0.0053 & -0.0097 \\
\hline & $(1.40)$ & $(-2.83)^{b}$ & $(1.39)$ & $(-2.81)^{b}$ & $(1.34)$ & $(-2.82)^{b}$ & $(1.38)$ & $(-2.74)^{b}$ \\
\hline \multirow[t]{2}{*}{ STD_ROA } & -0.2849 & -0.0343 & -0.2814 & -0.0375 & -0.2859 & -0.0945 & -0.2881 & -0.0839 \\
\hline & $(-3.42)^{a}$ & $(-0.40)$ & $(-3.37)^{a}$ & $(-0.43)$ & $(-3.41)^{a}$ & $(-1.10)$ & $(-3.44)^{\mathrm{a}}$ & $(-0.98)$ \\
\hline \multirow[t]{2}{*}{ ABNE } & -0.1286 & -0.1811 & -0.1308 & -0.1805 & -0.1310 & -0.1709 & -0.1309 & -0.1759 \\
\hline & $(-1.81)^{c}$ & $(-2.45)^{b}$ & $(-1.85)^{c}$ & $(-2.44)^{b}$ & $(-1.88)^{c}$ & $(-2.33)^{b}$ & $(-1.87)^{c}$ & $(-2.41)^{b}$ \\
\hline \multirow[t]{2}{*}{ SIZE } & 0.0271 & 0.0184 & 0.0273 & 0.0241 & 0.0292 & 0.0379 & 0.0292 & 0.0365 \\
\hline & $(5.64)^{\mathrm{a}}$ & $(3.00)^{a}$ & $(5.85)^{\mathrm{a}}$ & $(4.33)^{a}$ & $(6.77)^{\mathrm{a}}$ & $(7.18)^{a}$ & $(6.77)^{\mathrm{a}}$ & $(6.97)^{\mathrm{a}}$ \\
\hline \multirow[t]{2}{*}{ Constant } & 0.0969 & -0.1248 & 0.0900 & -0.1324 & 0.1138 & -0.1834 & 0.1178 & -0.1487 \\
\hline & $(0.94)$ & $(-1.85)^{c}$ & $(0.88)$ & $(-1.98)^{b}$ & $(1.08)$ & $(-2.74)^{b}$ & $(1.12)$ & $(-2.22)^{b}$ \\
\hline Year dummies & Yes & Yes & Yes & Yes & Yes & Yes & Yes & Yes \\
\hline Industry dummies & Yes & Yes & Yes & Yes & Yes & Yes & Yes & Yes \\
\hline Number of observations & 1,246 & 1,239 & 1,246 & 1,239 & 1,246 & 1,239 & 1,246 & 1,239 \\
\hline $\mathrm{R}^{2}$ & $10.69 \%$ & $15.54 \%$ & $10.45 \%$ & $16.21 \%$ & $10.56 \%$ & $18.38 \%$ & $10.64 \%$ & $18.27 \%$ \\
\hline
\end{tabular}

This table reports the results from the 2SLS estimation of the effect of excess control rights on the relation between voluntary disclosure and debt maturity using the sample-splitting technique. The groups Low EXCESS and High EXCESS include firms where the excess control rights of the controlling shareholder are below and above the median value, respectively. In all specifications, the dependent variable is debt maturity, DEBT_MATURITY, computed as the ratio of long-term debt to total debt. The full sample comprises 2,485 firm-year observations representing 440 French listed firms over the period 2007-2013. All the variables in the table are defined in Appendix 2. Year dummies and industry dummies following Campbell's (1996) classification are included in all the regressions. The $z$-statistics are reported in parentheses. The superscripts $a, b$, and c denote statistical significance at the $1 \%, 5 \%$, and $10 \%$ levels, respectively. 
Table 5

Robustness checks: Alternative variable measures

\begin{tabular}{|c|c|c|c|c|c|c|c|c|}
\hline \multirow[b]{2}{*}{ Variable } & \multirow{2}{*}{$\begin{array}{l}\text { Debt } \\
\text { maturity: } \\
\text { DEBT_ } \\
\text { MATURITY } \\
\text { DUMMY } \\
\text { (1) }\end{array}$} & \multirow{2}{*}{$\begin{array}{l}\text { Debt } \\
\text { maturity: } \\
\text { DEBT_- } \\
\text { MATURITY1 } \\
\text { (2) }\end{array}$} & \multicolumn{2}{|c|}{$\begin{array}{l}\text { Excess control = } \\
\text { EXCESS_RATIO }\end{array}$} & \multicolumn{2}{|c|}{$\begin{array}{c}\text { Excess control = } \\
\text { EXCESS_DIFF }\end{array}$} & \multicolumn{2}{|c|}{$\begin{array}{c}\text { Excess control = } \\
\text { EXCESS20 }\end{array}$} \\
\hline & & & $\begin{array}{l}\text { Low } \\
(3)\end{array}$ & $\begin{array}{l}\text { High } \\
(4)\end{array}$ & $\begin{array}{l}\text { Low } \\
(5)\end{array}$ & $\begin{array}{l}\text { High } \\
\text { (6) }\end{array}$ & Low (7) & $\begin{array}{l}\text { High } \\
(8)\end{array}$ \\
\hline OVERALL_VDI & $\begin{array}{l}0.3658 \\
(3.93)^{\mathrm{a}}\end{array}$ & $\begin{array}{l}0.2241 \\
(6.88)^{\mathrm{a}}\end{array}$ & $\begin{array}{l}0.1180 \\
(1.22)\end{array}$ & $\begin{array}{l}0.5229 \\
(6.83)^{\mathrm{a}}\end{array}$ & $\begin{array}{l}0.0391 \\
(0.41)\end{array}$ & $\begin{array}{l}0.5139 \\
(6.66)^{\mathrm{a}}\end{array}$ & $\begin{array}{l}0.1371 \\
(1.86)^{\mathrm{c}}\end{array}$ & $\begin{array}{l}0.4746 \\
(6.29)^{\mathrm{a}}\end{array}$ \\
\hline LEVERAGE & $\begin{array}{l}1.1187 \\
(3.53)^{\mathrm{a}}\end{array}$ & $\begin{array}{l}0.5223 \\
(3.13)^{\mathrm{a}}\end{array}$ & $\begin{array}{l}0.6472 \\
(1.73)^{\mathrm{c}}\end{array}$ & $\begin{array}{l}0.6400 \\
(3.17)^{\mathrm{a}}\end{array}$ & $\begin{array}{l}0.6589 \\
(2.19)^{\mathrm{b}}\end{array}$ & $\begin{array}{l}0.8631 \\
(3.15)^{\mathrm{a}}\end{array}$ & $\begin{array}{l}0.6718 \\
(1.86)^{\mathrm{c}}\end{array}$ & $\begin{array}{l}0.5932 \\
(3.00)^{\mathrm{a}}\end{array}$ \\
\hline ASSET_MATURITY & $\begin{array}{l}0.0037 \\
(1.47)\end{array}$ & $\begin{array}{l}0.0048 \\
(4.65)^{\mathrm{a}}\end{array}$ & $\begin{array}{l}0.0020 \\
(0.93)\end{array}$ & $\begin{array}{l}0.0039 \\
(1.77)^{\mathrm{c}}\end{array}$ & $\begin{array}{l}0.0027 \\
(1.30)\end{array}$ & $\begin{array}{l}0.0004 \\
(0.16)\end{array}$ & $\begin{array}{l}0.0029 \\
(1.27)\end{array}$ & $\begin{array}{l}0.0023 \\
(0.11)\end{array}$ \\
\hline МТВ & $\begin{array}{l}-0.0048 \\
(-1.11)\end{array}$ & $\begin{array}{l}-0.0074 \\
(-1.33)\end{array}$ & $\begin{array}{l}-0.0031 \\
(-0.86)\end{array}$ & $\begin{array}{l}-0.0044 \\
(-1.14)\end{array}$ & $\begin{array}{l}-0.0035 \\
(-0.98)\end{array}$ & $\begin{array}{l}-0.0015 \\
(-0.38)\end{array}$ & $\begin{array}{l}0.0044 \\
(1.19)\end{array}$ & $\begin{array}{l}-0.0097 \\
(-2.64)^{b}\end{array}$ \\
\hline STD_ROA & $\begin{array}{l}-0.1801 \\
(-1.82)^{\mathrm{c}}\end{array}$ & $\begin{array}{l}-0.1003 \\
(-3.06)^{\mathrm{a}}\end{array}$ & $\begin{array}{l}-0.2533 \\
(-2.98)^{\mathrm{a}}\end{array}$ & $\begin{array}{l}-0.0622 \\
(-0.73)\end{array}$ & $\begin{array}{l}-0.2444 \\
(-3.01)^{\mathrm{a}}\end{array}$ & $\begin{array}{l}-0.0699 \\
(-0.77)\end{array}$ & $\begin{array}{l}-0.2812 \\
(-3.34)^{\mathrm{a}}\end{array}$ & $\begin{array}{l}-0.0365 \\
(-0.43)\end{array}$ \\
\hline ABNE & $\begin{array}{l}-0.3427 \\
(-4.09)^{\mathrm{a}}\end{array}$ & $\begin{array}{l}-0.0629 \\
(-2.00)^{\mathrm{b}}\end{array}$ & $\begin{array}{l}-0.1505 \\
(-1.88)^{c}\end{array}$ & $\begin{array}{l}-0.1356 \\
(-2.01)^{\mathrm{b}}\end{array}$ & $\begin{array}{l}-0.1236 \\
(-1.81)^{\mathrm{c}}\end{array}$ & $\begin{array}{l}-0.1932 \\
(-2.51)^{\mathrm{b}}\end{array}$ & $\begin{array}{l}-0.1385 \\
(-1.78)^{\mathrm{c}}\end{array}$ & $\begin{array}{l}-0.1362 \\
(-2.03)^{\mathrm{b}}\end{array}$ \\
\hline SIZE & $\begin{array}{l}0.0324 \\
(5.65)^{\mathrm{a}}\end{array}$ & $\begin{array}{l}0.0034 \\
(1.80)^{\mathrm{c}}\end{array}$ & $\begin{array}{l}0.0198 \\
(3.88)^{\mathrm{a}}\end{array}$ & $\begin{array}{l}0.0228 \\
(4.36)^{\mathrm{a}}\end{array}$ & $\begin{array}{l}0.0276 \\
(6.18)^{\mathrm{a}}\end{array}$ & $\begin{array}{l}0.0130 \\
(1.92)^{\mathrm{b}}\end{array}$ & $\begin{array}{l}0.02445 \\
(4.76)^{\mathrm{a}}\end{array}$ & $\begin{array}{l}0.0224 \\
(4.54)^{\mathrm{a}}\end{array}$ \\
\hline Constant & $\begin{array}{l}-0.1215 \\
(0.85)\end{array}$ & $\begin{array}{l}-0.0295 \\
(-0.61)\end{array}$ & $\begin{array}{l}0.2142 \\
(2.03)^{\mathrm{b}}\end{array}$ & $\begin{array}{l}-0.1520 \\
(-2.30)^{b}\end{array}$ & $\begin{array}{l}0.1578 \\
(1.63)\end{array}$ & $\begin{array}{l}-0.1374 \\
(-1.93)^{c}\end{array}$ & $\begin{array}{l}0.1232 \\
(1.17)\end{array}$ & $\begin{array}{l}-0.1057 \\
(-1.63)\end{array}$ \\
\hline Year dummies & Yes & Yes & Yes & Yes & Yes & Yes & Yes & Yes \\
\hline Industry dummies & Yes & Yes & Yes & Yes & Yes & Yes & Yes & Yes \\
\hline $\begin{array}{l}\text { Number of } \\
\text { observations }\end{array}$ & 2,485 & 2,485 & 1,237 & 1,248 & 1,247 & 1,238 & 1,234 & 1,251 \\
\hline $\mathrm{R}^{2}$ & $4.84 \%$ & $35.52 \%$ & $8.27 \%$ & $18.68 \%$ & $16.65 \%$ & $5.51 \%$ & $10.36 \%$ & $17.84 \%$ \\
\hline
\end{tabular}

This table reports the results from a 2SLS estimation using alternative proxies for debt maturity (two first specifications) and excess control rights (last six specifications). In specification (1), the dependent variable is DEBT_MATURITY DUMMY, a dummy that equals 1 when the ratio of long-term debt to total debt exceeds $50 \%$, and 0 otherwise. In specification (2), the dependent variable is DEBT_MATURITY1, measured as the difference between total liabilities and current liabilities, divided by total liabilities. In specifications (3) to (8), the dependent variable is DEBT_MATURITY, computed as the ratio of long-term debt to total debt. The low- and high-excess control groups include firms where the excess control rights of the controlling shareholder are below and above the median value, respectively. The variable EXCESS_RATIO is the ratio of the controlling shareholder's control rights to cash-flow rights; EXCESS_DIFF is the difference between the controlling shareholder's control rights and cash-flow rights; and EXCESS20 is the excess control rights of the controlling shareholder, considering the $20 \%$ control level, computed as the difference between the controlling shareholder's control rights and cash-flow rights, divided by the controlling shareholder's control rights. The full sample comprises 2,485 firm-year observations representing 440 French listed firms over the period 2007-2013. The other variables in the table are defined in Appendix 2. Year dummies and industry dummies following Campbell's (1996) classification are included in all the regressions. The $z$-statistics are reported in parentheses. The superscripts $\mathrm{a}, \mathrm{b}$, and c denote statistical significance at the $1 \%, 5 \%$, and $10 \%$ levels, respectively. 
Table 6

Robustness checks: Alternative sample compositions

\begin{tabular}{|c|c|c|c|c|c|}
\hline Variable & $\begin{array}{c}\text { Excluding } \\
\text { firms with } \\
\text { institutional } \\
\text { control (1) }\end{array}$ & $\begin{array}{l}\text { Excluding } \\
\text { widely held } \\
\text { firms } \\
(2)\end{array}$ & $\begin{array}{l}\text { Low cash- } \\
\text { flow rights } \\
\text { only (3) }\end{array}$ & $\begin{array}{l}\text { Excluding firms } \\
\text { with multiple } \\
\text { large } \\
\text { shareholders (4) }\end{array}$ & $\begin{array}{l}\text { Excluding } \\
\text { group- } \\
\text { affiliated } \\
\text { firms (5) }\end{array}$ \\
\hline \multirow[t]{2}{*}{ OVERALL_VDI } & 0.3054 & 0.3297 & 0.50006 & 0.4704 & 0.3510 \\
\hline & $(5.18)^{\mathrm{a}}$ & $(5.62)^{a}$ & $(5.44)^{\mathrm{a}}$ & $(4.18)^{\mathrm{a}}$ & $(5.60)^{\mathrm{a}}$ \\
\hline \multirow[t]{2}{*}{ LEVERAGE } & 0.6392 & 0.6786 & 1.0374 & 1.3149 & 0.5348 \\
\hline & $(3.08)^{\mathrm{a}}$ & $(3.66)^{b}$ & $(4.59)^{\mathrm{a}}$ & $(2.67)^{\mathrm{b}}$ & $(2.11)^{b}$ \\
\hline \multirow[t]{2}{*}{ ASSET_MATURITY } & 0.0038 & 0.0027 & 0.0009 & 0.0053 & 0.0042 \\
\hline & $(2.33)^{b}$ & $(1.69)^{\mathrm{c}}$ & $(0.42)$ & $(2.04)^{\mathrm{b}}$ & $(2.16)^{b}$ \\
\hline \multirow[t]{2}{*}{ МТВ } & -0.0029 & -0.0020 & 0.0015 & 0.0162 & -0.0006 \\
\hline & $(-1.06)$ & $(-0.70)$ & $(0.38)$ & $(2.39)^{\mathrm{b}}$ & $(-0.18)$ \\
\hline \multirow[t]{2}{*}{ STD_ROA } & -0.1824 & -0.1165 & -0.2135 & -0.3600 & -0.1204 \\
\hline & $(-2.90)^{\mathrm{a}}$ & $(-1.79)^{\mathrm{c}}$ & $(-2.30)^{b}$ & $(-2.91)^{\mathrm{a}}$ & $(-1.74)^{c}$ \\
\hline \multirow{2}{*}{ ABNE } & -0.1375 & -0.1320 & -0.1912 & -0.2225 & -0.1555 \\
\hline & $(-2.57)^{\mathrm{b}}$ & $(-2.48)^{\mathrm{b}}$ & $(-2.82)^{\mathrm{b}}$ & $(-1.59)$ & $(-2.65)^{b}$ \\
\hline \multirow[t]{2}{*}{ SIZE } & 0.0238 & 0.0220 & 0.0190 & 0.0228 & 0.0222 \\
\hline & $(6.52)^{\mathrm{a}}$ & $(5.37)^{\mathrm{a}}$ & $(3.67)^{\mathrm{a}}$ & $(2.92)^{a}$ & $(4.79)^{\mathrm{a}}$ \\
\hline \multirow[t]{2}{*}{ Constant } & 0.0539 & 0.0543 & -0.0115 & -0.01858 & -0.0027 \\
\hline & $(0.62)$ & $(-0.62)$ & $(-0.11)$ & $(-1.29)$ & $(-0.02)$ \\
\hline Year dummies & Yes & Yes & Yes & Yes & Yes \\
\hline Industry dummies & Yes & Yes & Yes & Yes & Yes \\
\hline Number of observations & 2,279 & 2,043 & 1,234 & 606 & 1785 \\
\hline $\mathrm{R}^{2}$ & $13.02 \%$ & $11.99 \%$ & $11.86 \%$ & $9.58 \%$ & $12.40 \%$ \\
\hline
\end{tabular}

This table reports the results from a 2SLS estimation of the effect of voluntary disclosure on debt maturity using different sample compositions. In specification (1), firms having an institutional controlling shareholder are excluded from the sample of 4,285 firm-year observations. In specification (2), widely held firms (i.e., without a controlling shareholder when considering the $10 \%$ control level) are excluded from the analysis. In specification (3), only firms where the controlling shareholder has low cash-flow rights (i.e., less than $25 \%$ ) are included. In specification (4), the results are obtained after excluding firms with more than one controlling shareholder (considering the 10\% control level). In specification (5), we replicate our results after discarding group-affiliated firms. In all specifications, the dependent variable is debt maturity, DEBT_MATURITY, computed as the ratio of long-term debt to total debt. The full sample comprises 2,485 firm-year observations representing 440 French listed firms over the period 2007-2013. All the variables in the table are defined in Appendix 2. Year dummies and industry dummies following Campbell's (1996) classification are included in all the regressions. The $z$-statistics are reported in parentheses. The superscripts $\mathrm{a}, \mathrm{b}$, and c denote statistical significance at the $1 \%, 5 \%$, and $10 \%$ levels, respectively. 
Table 7

Robustness checks: Alternative statistical techniques

\begin{tabular}{|c|c|c|c|c|c|c|}
\hline Variable & $\begin{array}{l}\text { Tobit } \\
(1)\end{array}$ & $\begin{array}{c}\text { OLS } \\
\text { clustering by } \\
\text { firm (2) }\end{array}$ & $\begin{array}{c}\text { Fama- } \\
\text { MacBeth } \\
\text { (3) }\end{array}$ & $\begin{array}{c}\text { Fama- } \\
\text { MacBeth } \\
\text { with Newey- } \\
\text { West (4) }\end{array}$ & $\begin{array}{c}\text { Random } \\
\text { effect } \\
(5)\end{array}$ & $\begin{array}{c}\text { System } \\
\text { GMM (6) }\end{array}$ \\
\hline LAG OVERALL_VDI & & & & & & $\begin{array}{l}0.0963 \\
(10.31)^{\mathrm{a}}\end{array}$ \\
\hline OVERALL_VDI & $\begin{array}{l}0.3799 \\
(6.50)^{\mathrm{a}}\end{array}$ & $\begin{array}{l}0.3401 \\
(3.44)^{\mathrm{a}}\end{array}$ & $\begin{array}{l}0.4107 \\
(13.84)^{\mathrm{a}}\end{array}$ & $\begin{array}{l}0.4107 \\
(15.12)^{a}\end{array}$ & $\begin{array}{l}0.1833 \\
(2.34)^{\mathrm{b}}\end{array}$ & $\begin{array}{l}0.3225 \\
(5.30)^{a}\end{array}$ \\
\hline LEVERAGE & $\begin{array}{l}0.3536 \\
(9.35)^{\mathrm{a}}\end{array}$ & $\begin{array}{l}0.2995 \\
(4.47)^{\mathrm{a}}\end{array}$ & $\begin{array}{l}0.2798 \\
(7.85)^{\mathrm{a}}\end{array}$ & $\begin{array}{l}0.2798 \\
(6.98)^{\mathrm{a}}\end{array}$ & $\begin{array}{l}0.2850 \\
(6.04)^{\mathrm{a}}\end{array}$ & $\begin{array}{l}0.2603 \\
(5.19)^{\mathrm{a}} \\
0.000\end{array}$ \\
\hline ASSET_MATURITY & $\begin{array}{l}0.0049 \\
(3.90)^{\mathrm{a}}\end{array}$ & $\begin{array}{l}0.0047 \\
(2.51)^{\mathrm{b}}\end{array}$ & $\begin{array}{l}0.0038 \\
(6.19)^{\mathrm{a}}\end{array}$ & $\begin{array}{l}0.0038 \\
(6.42)^{\mathrm{a}}\end{array}$ & $\begin{array}{c}0.0023 \\
(1.41)\end{array}$ & $\begin{array}{l}0.0031 \\
(2.25) b\end{array}$ \\
\hline МТВ & $\begin{array}{l}-0.0041 \\
(-1.49)\end{array}$ & $\begin{array}{l}-0.0024 \\
(-0.73)\end{array}$ & $\begin{array}{l}-0.0033 \\
(-1.29)\end{array}$ & $\begin{array}{l}-0.0033 \\
(-1.21)\end{array}$ & $\begin{array}{l}0.0021 \\
(1.01)\end{array}$ & $\begin{array}{l}0.0002 \\
(2.44)^{\mathrm{b}}\end{array}$ \\
\hline STD_ROA & $\begin{array}{l}-0.1857 \\
(-2.91)^{\mathrm{a}}\end{array}$ & $\begin{array}{l}-0.1623 \\
(-2.15)^{b}\end{array}$ & $\begin{array}{l}-0.1686 \\
(-3.21)^{b}\end{array}$ & $\begin{array}{l}-0.1686 \\
(-3.25)^{b}\end{array}$ & $\begin{array}{l}-0.1276 \\
(-2.48)^{b}\end{array}$ & $\begin{array}{l}-0.1484 \\
(-2.97)^{\mathrm{a}}\end{array}$ \\
\hline ABNE & $\begin{array}{l}-0.0883 \\
(-2.01)^{b}\end{array}$ & $\begin{array}{l}-0.0966 \\
(-2.28)^{b}\end{array}$ & $\begin{array}{l}-0.1281 \\
(-3.13)^{b}\end{array}$ & $\begin{array}{l}-0.1281 \\
(-3.33)^{b}\end{array}$ & $\begin{array}{c}-0.0414 \\
(-1.30)\end{array}$ & $\begin{array}{l}-0.0513 \\
(-1.80)^{c}\end{array}$ \\
\hline SIZE & $\begin{array}{l}0.0272 \\
(7.85)^{\mathrm{c}}\end{array}$ & $\begin{array}{l}0.0247 \\
(4.17)^{\mathrm{a}}\end{array}$ & $\begin{array}{l}0.0211 \\
(11.47)^{\mathrm{a}}\end{array}$ & $\begin{array}{l}0.0211 \\
(14.97)^{\mathrm{a}}\end{array}$ & $\begin{array}{l}0.0335 \\
(6.53)^{\mathrm{a}}\end{array}$ & $\begin{array}{l}0.0253 \\
(5.62)^{\mathrm{a}}\end{array}$ \\
\hline Constant & $\begin{array}{l}0.0150 \\
(0.16)\end{array}$ & $\begin{array}{l}0.0728 \\
(-0.98)\end{array}$ & $\begin{array}{l}-0.0015 \\
(-0.04)\end{array}$ & $\begin{array}{r}-0.0015 \\
(-0.03)\end{array}$ & $\begin{array}{l}0.0675 \\
(0.40)\end{array}$ & $\begin{array}{r}-0.0014 \\
(-0.03)\end{array}$ \\
\hline Year dummies & Yes & Yes & No & No & Yes & Yes \\
\hline Industry dummies & Yes & Yes & Yes & Yes & Yes & Yes \\
\hline $\begin{array}{l}\text { Number of } \\
\text { observations }\end{array}$ & 2,485 & 2,485 & 2,485 & 2,485 & 2,485 & 2,045 \\
\hline Pseudo- $\mathrm{R}^{2}$ & $23.34 \%$ & & & & & $\begin{array}{l}\mathrm{AR}(1) \\
0.000\end{array}$ \\
\hline $\mathrm{R}^{2}$ & & $15.26 \%$ & & & $19.16 \%$ & $\begin{array}{l}\mathrm{AR}(2) \\
0.649\end{array}$ \\
\hline Average $\mathrm{R}^{2}$ & & & $14.65 \%$ & $14.65 \%$ & & $\begin{array}{l}\text { Hansen } \\
\text { test } 0.919\end{array}$ \\
\hline
\end{tabular}

This table reports the results from a 2SLS estimation of the effect of voluntary disclosure on debt maturity using different statistical techniques. In all specifications, the dependent variable is debt maturity, DEBT_MATURITY, computed as the ratio of long-term debt to total debt. All the variables in the table are defined in Appendix 2. Year dummies are included in specifications (1), (2), (5), and (6). Industry dummies following Campbell's (1996) classification are included in all the regressions. The statistics are reported in parentheses. The superscripts $a, b$, and c denote statistical significance at the $1 \%, 5 \%$, and $10 \%$ levels, respectively. 
Table 8

Additional analysis

\begin{tabular}{|c|c|c|}
\hline & $\begin{array}{l}\text { Public debt/ private debt } \\
\text { (1) }\end{array}$ & $\begin{array}{l}\text { Equity/debt } \\
\text { (2) }\end{array}$ \\
\hline \multirow[t]{2}{*}{ OVERALL_VDI } & 0.1714 & 0.6681 \\
\hline & $(2.99)^{a}$ & $(2.43)^{b}$ \\
\hline \multirow[t]{2}{*}{ LEVERAGE } & -0.1461 & -5.4502 \\
\hline & $(3.29)^{\mathrm{a}}$ & $(-23.94)^{a}$ \\
\hline \multirow[t]{2}{*}{ TANGIBILITY } & -0.0672 & -0.0481 \\
\hline & $(-2.42)^{\mathrm{b}}$ & $(-1.84)^{\mathrm{c}}$ \\
\hline \multirow[t]{2}{*}{ ROA } & 0.3984 & -37.472 \\
\hline & $(1.53)$ & $(-17.52)^{a}$ \\
\hline \multirow[t]{2}{*}{ MTB } & -0.0020 & 0.1899 \\
\hline & $(-0.45)$ & $(8.13)^{a}$ \\
\hline \multirow[t]{2}{*}{ SIZE } & 0.0606 & -0.4669 \\
\hline & $(17.33)^{\mathrm{a}}$ & $(-2.75)^{\mathrm{a}}$ \\
\hline \multirow[t]{2}{*}{ Z_SCORE } & -0.03889 & 3.7473 \\
\hline & $(-1.76)^{c}$ & $(21.05)^{\mathrm{a}}$ \\
\hline \multirow[t]{2}{*}{ Constant } & -0.3055 & 0.6364 \\
\hline & $(-3.34)^{a}$ & (1.47) \\
\hline Year dummies & Yes' & Yes' \\
\hline Industry dummies & Yes & Yes \\
\hline Number of observations & 2,111 & 2,485 \\
\hline Adjusted-R² & $21.52 \%$ & $59.73 \%$ \\
\hline \multicolumn{3}{|c|}{$\begin{array}{l}\text { This table reports the results of OLS regressions estimating the effect of voluntary } \\
\text { disclosure on different types of external financing. In specification }(1) \text {, the dependent } \\
\text { variable is the ratio of public debt to total debt. In specification }(2) \text {, the dependent } \\
\text { variable is the ratio of equity to debt; TANGIBILITY is the ratio of net plant, property } \\
\text { and equipment to total assets; ROA is profitability, measured as return on assets, } \\
\text { Z_SCORE is Altman's }(1968) Z \text {-score, calculated as }\left(1.2^{*} \text { working capital }+1.4^{*} \text { retained }\right. \\
\left.\text { earnings }+3.3^{*} \text { earnings before interest and taxes }+0.999^{*} \text { sales }\right) / \text { total assets }+ \\
0.6^{*}(\text { market value of equity/book value of debt). All the variables in the table are } \\
\text { defined in Appendix } 2 \text {. Year dummies and industry dummies following Campbell's } \\
\text { (1996) classification are included in all the regressions. The } t \text {-statistics are reported in } \\
\text { parentheses. The superscripts a, b, and c denote statistical significance at the } 1 \%, 5 \% \text {, } \\
\text { and } 10 \% \text { levels, respectively. }\end{array}$} \\
\hline
\end{tabular}


Table 9

Endogeneity issues

\begin{tabular}{|c|c|c|c|c|}
\hline Variable & $\begin{array}{l}\text { Second-stage } \\
\text { regression } \\
\text { (1) }\end{array}$ & $\begin{array}{l}\text { Second-stage } \\
\text { GMM } \\
\text { (2) }\end{array}$ & \multicolumn{2}{|l|}{$\begin{array}{l}\text { First-stage } \\
\text { regression } \\
\text { (3) } \\
\text { Variable }\end{array}$} \\
\hline OVERALL_VDI & $\begin{array}{l}0.4989 \\
(2.76)^{\mathrm{b}}\end{array}$ & $\begin{array}{l}0.4771 \\
(2.85)^{\mathrm{b}}\end{array}$ & AGE & $\begin{array}{l}-0.0087 \\
(-3.53)^{\mathrm{a}}\end{array}$ \\
\hline LEVSERAGE & $\begin{array}{l}0.4549 \\
(2.79)^{\mathrm{b}}\end{array}$ & $\begin{array}{l}0.6778 \\
(4.33)^{\mathrm{a}}\end{array}$ & ANALYST & $\begin{array}{l}0.0500 \\
(14.47)^{\mathrm{a}}\end{array}$ \\
\hline ASSET_MATURITY & $\begin{array}{l}0.0042 \\
(2.86)^{\mathrm{b}}\end{array}$ & $\begin{array}{l}0.0033 \\
(2.28)^{\mathrm{b}}\end{array}$ & ROA & $\begin{array}{l}0.0008 \\
(0.11)\end{array}$ \\
\hline MTB & $\begin{array}{l}-0.0030 \\
(-1.15)\end{array}$ & $\begin{array}{l}-0.0041 \\
(-1.45)\end{array}$ & MTB & $\begin{array}{l}0.0007 \\
(1.87)^{c}\end{array}$ \\
\hline STD_ROA & $\begin{array}{l}-0.1605 \\
(-2.71)^{\mathrm{b}}\end{array}$ & $\begin{array}{l}-0.1409 \\
(-2.39)^{\mathrm{b}}\end{array}$ & STD_ROA & $\begin{array}{l}-0.0262 \\
(-2.01)^{\mathrm{b}}\end{array}$ \\
\hline ABNE & $\begin{array}{c}-0.1132 \\
(-2.33)^{\mathrm{b}}\end{array}$ & $\begin{array}{c}-0.1553 \\
(-3.14)^{\mathrm{a}}\end{array}$ & CONCENTRATION & $\begin{array}{l}-0.0003 \\
(-2.18)^{\mathrm{b}}\end{array}$ \\
\hline \multirow[t]{3}{*}{ SIZE } & $\begin{array}{l}0.0190 \\
(3.28)^{\mathrm{a}}\end{array}$ & $\begin{array}{c}0.0172 \\
(3.08)^{\mathrm{a}}\end{array}$ & SIZE & $\begin{array}{l}0.0124 \\
(7.75)^{\mathrm{a}}\end{array}$ \\
\hline & & & ISSUANCE & $\begin{array}{l}0.0048 \\
(0.61)\end{array}$ \\
\hline & & & LITIGATION & $\begin{array}{l}0.0105 \\
(0.21)\end{array}$ \\
\hline Constant & $\begin{array}{l}0.0415 \\
(0.46)\end{array}$ & $0.0471(0.48)$ & Constant & $\begin{array}{l}0.2898 \\
(9.07)^{\mathrm{a}}\end{array}$ \\
\hline Year dummies & Yes & Yes & & Yes \\
\hline Industry dummies & Yes & Yes & & Yes \\
\hline Number of observations & 2,485 & 2,485 & & 2,485 \\
\hline Adjusted-R ${ }^{2}$ & $14.25 \%$ & $10.89 \%$ & & $34.96 \%$ \\
\hline $\begin{array}{l}\text { Wu-Hausman } \\
\text { GMM C statistic }\end{array}$ & $p$-value 0.006 & & Partial F-statistic & 20.2267 \\
\hline \multicolumn{5}{|c|}{$\begin{array}{l}\text { This table reports the results from 2SLS regressions considering voluntary disclosure as } \\
\text { endogenous. In specifications (1) and (2), the dependent variable is debt maturity, } \\
\text { DEBT_MATURITY, computed as the ratio of long-term debt to total debt. The results of the first } \\
\text { stage of the 2SLS regression (with voluntary disclosure as the dependent variable) are reported in } \\
\text { specification (3). The full sample comprises 2,485 firm-year observations representing } 440 \text { French } \\
\text { listed firms over the period 2007-2013. All the variables in the table are defined in Appendix } 2 \text {. Year } \\
\text { dummies and industry dummies following Campbell's (1996) classification are included in all the } \\
\text { regressions. The statistics are reported in parentheses. The superscripts a, b, and c denote statistical } \\
\text { significance at the } 1 \%, 5 \% \text {, and } 10 \% \text { levels, respectively. }\end{array}$} \\
\hline
\end{tabular}

